\title{
Development of an Activation Analysis Methodology to Support the Disposal of the High Flux Isotope Reactor Metal Pool Waste
}

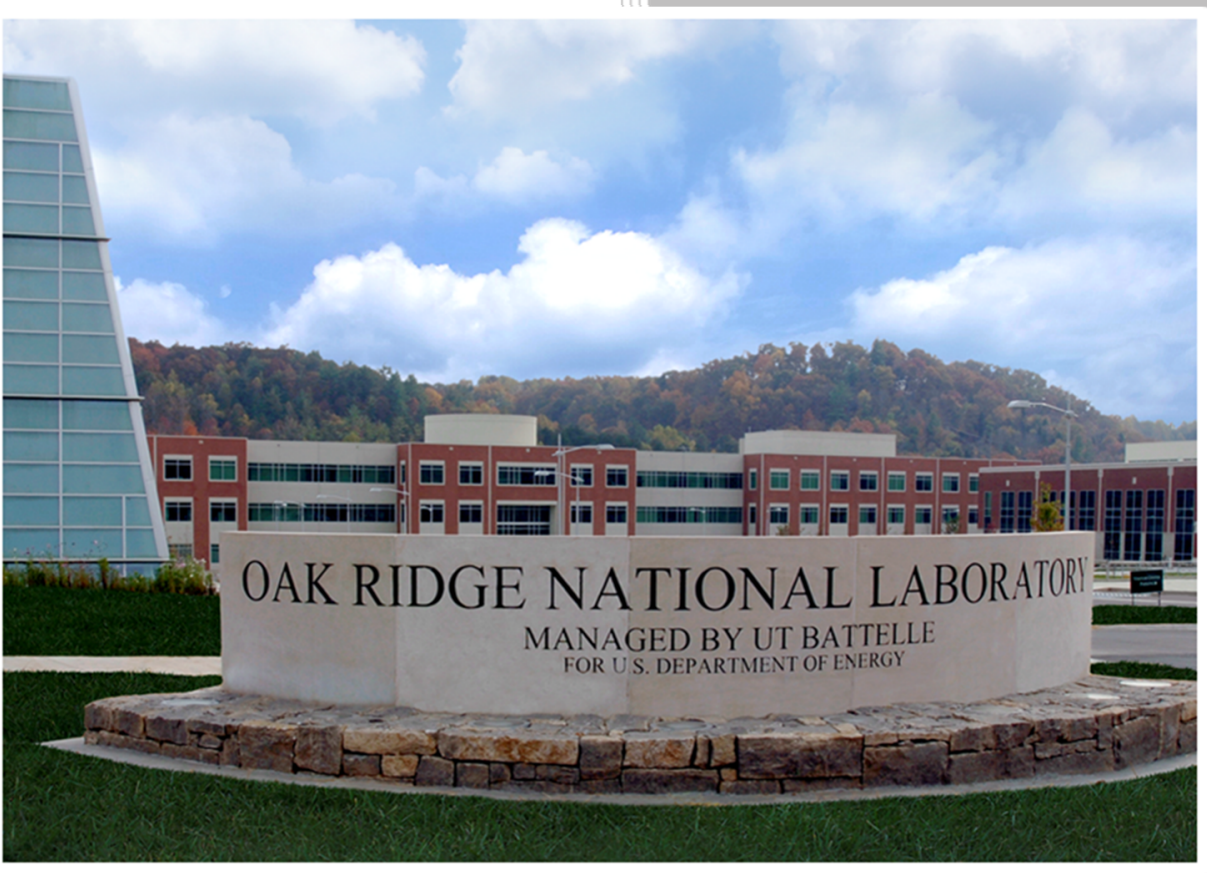

Scott A. Byers

Jorge Navarro

Randal E. Pudelek

Geoffrey G. Deichert

Young Soo Kwon

Russ Wools

Mathew A. Grooms

September 27, 2021 


\title{
DOCUMENT AVAILABILITY
}

Reports produced after January 1, 1996, are generally available free via US Department of Energy (DOE) SciTech Connect.

Website www.osti.gov

Reports produced before January 1, 1996, may be purchased by members of the public from the following source:

\author{
National Technical Information Service \\ 5285 Port Royal Road \\ Springfield, VA 22161 \\ Telephone 703-605-6000 (1-800-553-6847) \\ TDD 703-487-4639 \\ Fax 703-605-6900 \\ E-mail info@ntis.gov \\ Website http://classic.ntis.gov/
}

Reports are available to DOE employees, DOE contractors, Energy Technology Data Exchange representatives, and International Nuclear Information System representatives from the following source:

Office of Scientific and Technical Information

PO Box 62

Oak Ridge, TN 37831

Telephone 865-576-8401

Fax 865-576-5728

E-mail reports@osti.gov

Website http://www.osti.gov/contact.html

This report was prepared as an account of work sponsored by an agency of the United States Government. Neither the United States Government nor any agency thereof, nor any of their employees, makes any warranty, express or implied, or assumes any legal liability or responsibility for the accuracy, completeness, or usefulness of any information, apparatus, product, or process disclosed, or represents that its use would not infringe privately owned rights. Reference herein to any specific commercial product, process, or service by trade name, trademark, manufacturer, or otherwise, does not necessarily constitute or imply its endorsement, recommendation, or favoring by the United States Government or any agency thereof. The views and opinions of authors expressed herein do not necessarily state or reflect those of the United States Government or any agency thereof. 
Nuclear Energy and Fuel Cycle Division

Development of an Activation Analysis Methodology to Support the Disposal of the High Flux Isotope Reactor Metal Pool Waste

\author{
Scott A. Byers \\ Jorge Navarro \\ Randal E. Pudelek \\ Geoffrey G. Deichert \\ Young Soo Kwon \\ Russ Wools \\ Mathew A. Grooms
}

Date Published: September 27, 2021

Prepared by

OAK RIDGE NATIONAL LABORATORY

Oak Ridge, TN 37831-6283

managed by

UT-BATTELLE, LLC

for the

US DEPARTMENT OF ENERGY

under contract DE-AC05-00OR22725 



\section{CONTENTS}

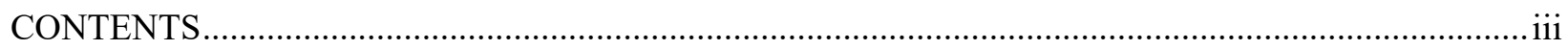

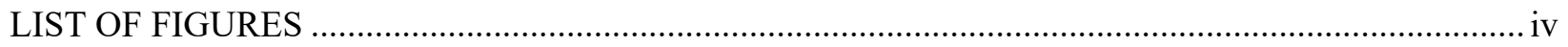

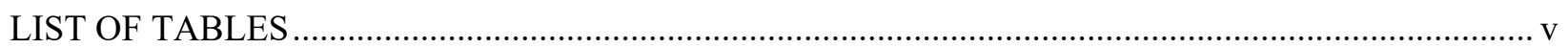

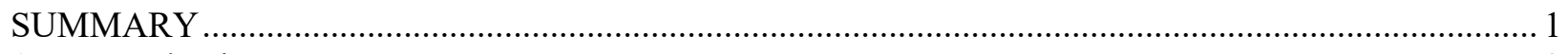

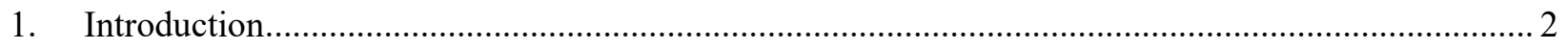

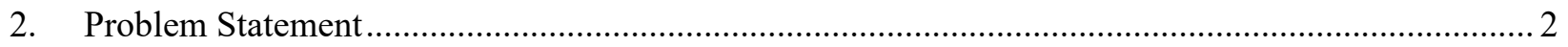

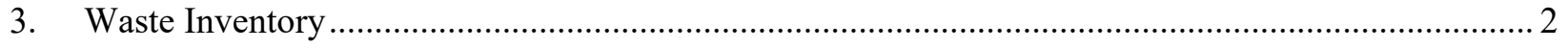

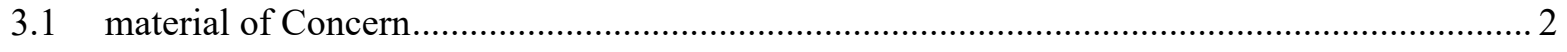

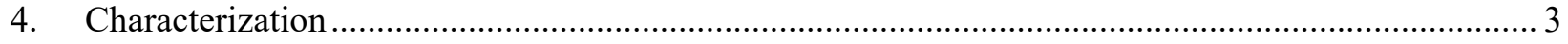

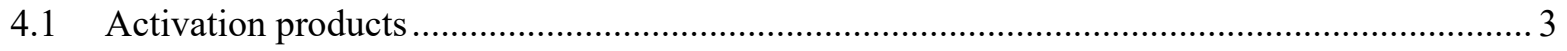

4.2 MicroShield Analysis Description and methodology ....................................................... 6

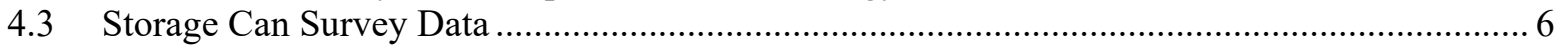

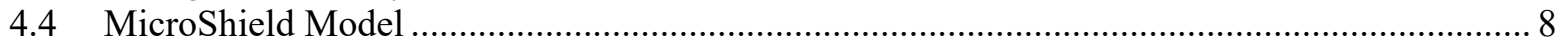

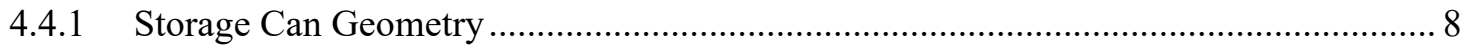

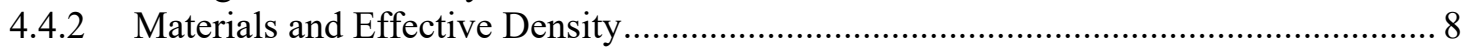

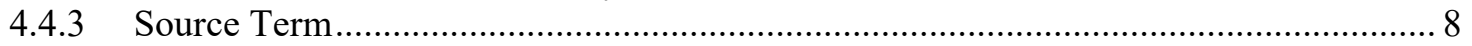

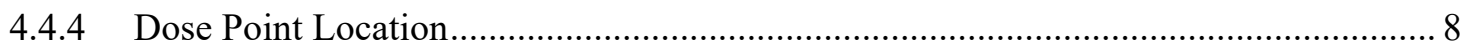

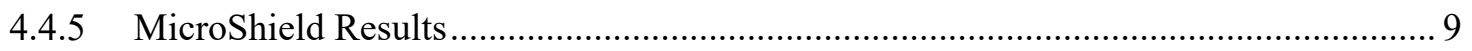

5. Calculation and Evaluation of Model Results .......................................................................... 9

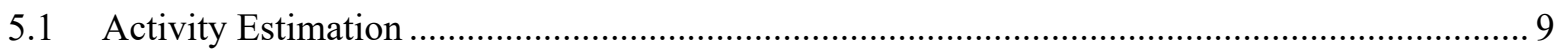

5.1.1 Additional Experiment Facility Tubing Model.................................................... 10

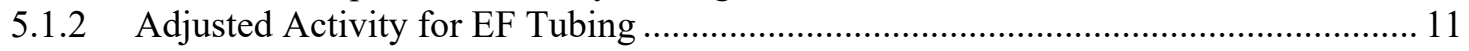

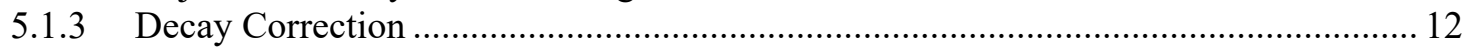

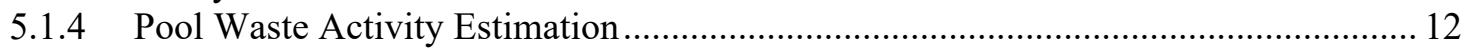

5.1.5 Pool Waste Activity Assessment from On-Contact Exposure Rates ........................... 13

5.1.6 Total Radionuclide Activities ............................................................................. 14

5.2 Effect of irradiation Time, Neutron Flux and Decay on Nuclide Fraction and Estimated

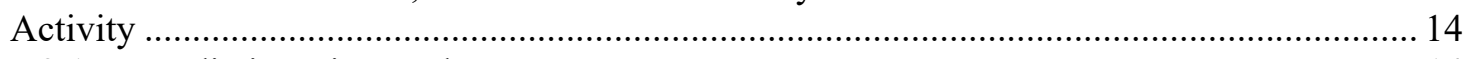

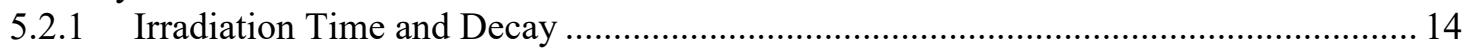

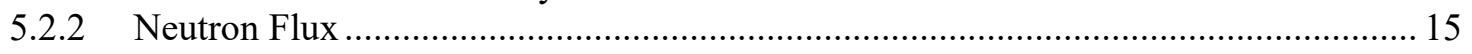

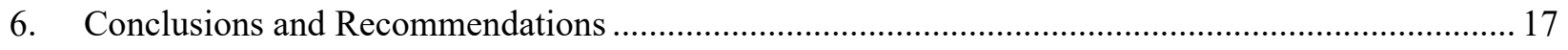

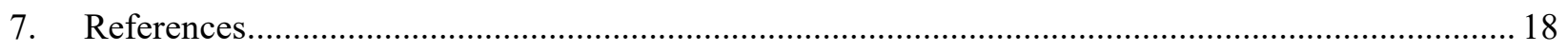

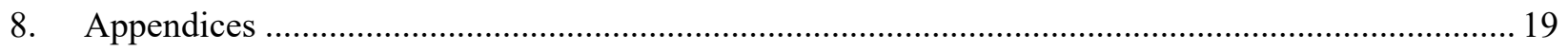

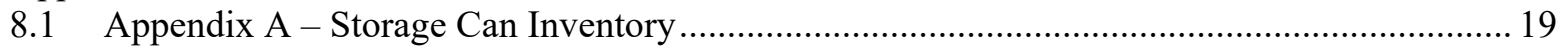

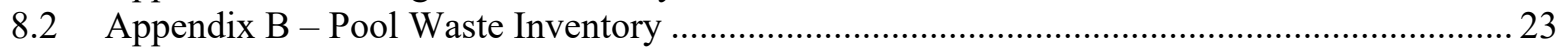

8.3 Appendix C - Storage Can MicroShield Model …............................................................. 24

8.4 Appendix D - EF Tube MicroShield Model................................................................... 27

8.5 Appendix E - UnderWater On Contact MicroShield Model ................................................. 30 


\section{LIST OF FIGURES}

Figure 1: Storage Can Survey Data from HFIR-537801 .............................................................

Figure 2: MicroShield Model and Survey Data Comparison at 3.082 Ci of Co-60.............................. 10

Figure 3: EF Tubing Model Dose Points (Plan View in inches)......................................................... 11 


\section{LIST OF TABLES}

Table 1: Waste Material Summary ........................................................................................................ 3

Table 2. (100\%) Aluminum Isotopic Distribution for Cage Location (Mar-2021) ................................. 4

Table 3. (100\%) Stainless Steel Isotopic Distribution for Cage Location (Mar-2021)............................. 4

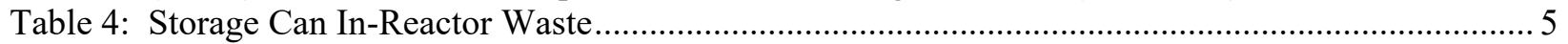

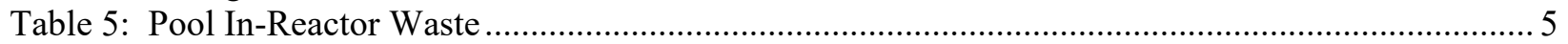

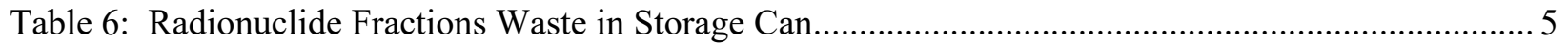

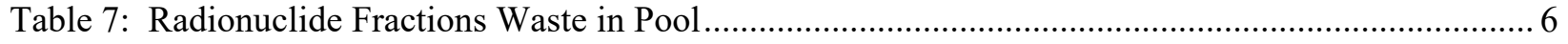

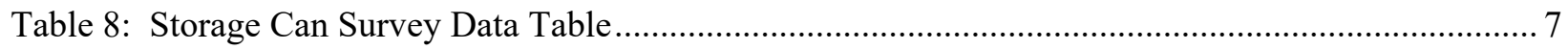

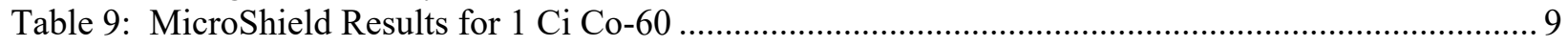

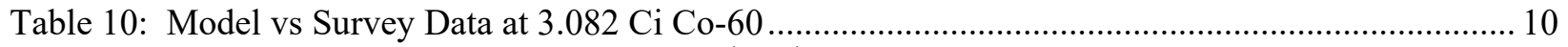

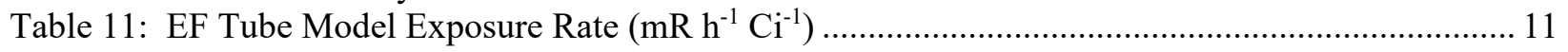

Table 12: Exposure Rates for Adjusted Co-60 Activity of $3.466 \mathrm{Ci}$.................................................... 12

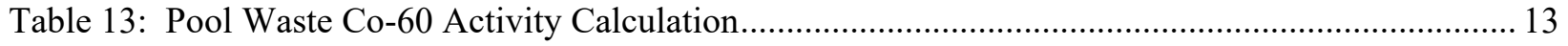

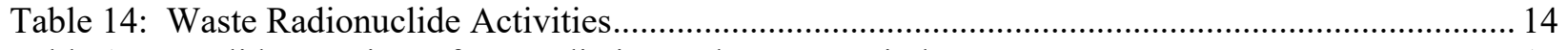

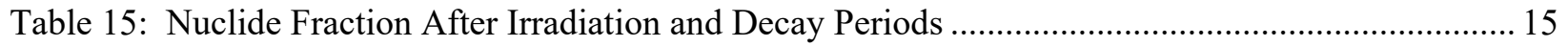

Table 16. (100\%) Aluminum Isotopic Distribution for Flux Trap Location (Mar-2021) ....................... 16

Table 17. (100\%) Stainless Steel Isotopic Distribution for Flux Trap Location (Mar-2021)................... 16 


\section{SUMMARY}

During operation and maintenance of the High Flux Isotope Reactor (HFIR), metal waste from reactor components is generated. Due to space limitations in the pool fuel storage, it is necessary to remove the waste and send it to off-site disposal. Most of this waste was in the reactor and is radioactive through neutron activation. Prior to shipping and disposal at a waste disposal facility, the radiological activity of the waste must be determined. Therefore, a conservative methodology to characterize the radiological activity of the waste must be performed. The methodology used was based on being able to determine a conservative overall activity and radionuclide inventory based on radiological survey data and neutron activation products for the materials present. 


\section{INTRODUCTION}

The beryllium change out for High Isotope Flux reactor (HFIR) is scheduled for the year 2023. As part of the preparations needed to ensure that a successful core internal change out can be performed, legacy materials need to be removed from the storage pool and they need to be relocated to a long-term waste facility. The removal of the legacy material is mainly to assure that the operations personnel have enough space to maneuver during the core change out as well as to store new material that will be removed from the reactor. Many of the legacy parts that are in the process of being removed is waste from reactor component maintenance and repair. Prior to the removal and transportation of the waste from the fuel storage pool to a permanent waste site a determination of the activation rate and radionuclide inventory is needed for transportation and disposal site purposes.

\section{PROBLEM STATEMENT}

The radioactive activity of waste items that have been activated in the reactor can be ascertained using both measured exposure rate(s) and the fraction of radionuclides present in the items. Since the reactor parts are primarily composed of aluminum alloys and stainless steel, the main challenge is to determine the fraction of each radionuclide present in the waste with relative accuracy. To overcome this challenge, a strategy that focused on using computational analysis to determine activation products associated with aluminum and stainless steel in the reactor was used. Exposure rate measurements were used along with the inventory of materials, and the computational models of material activation to calculate a conservative radionuclide characterization and total activity. Specifically, given a radionuclide distribution and a dose-to-curie model the total activity can be derived by estimating the activity of gamma emitting nuclides.

\section{WASTE INVENTORY}

\subsection{MATERIAL OF CONCERN}

In preparation for disposal waste from the pool, items were segregated and placed in a large pool storage can. Reactor operators segregated these items based on measured underwater on-contact dose rates, with the parts having an acceptable dose rate being designated for disposal. Items with an excessive dose rate are being held for future disposal to allow for decay to acceptable levels. After the storage can was filled, additional items continued to be segregated for disposal and placed in designated locations in the pool. Part of the segregation process involved determining the part type, construction material, mass, and location in the reactor for each item. Some parts for disposal were not installed in the reactor and should have a relatively low activation. These parts are small, suspected contaminated items that fill voids in the can. 
A total of $484.59 \mathrm{lbs} .(2.1981 \mathrm{E}+05 \mathrm{~g})$ consisting of $227.09 \mathrm{lbs} .(1.03031 \mathrm{E}+05 \mathrm{~g})$ of aluminum and $257.50 \mathrm{lbs}$. of steel $(1.1680 \mathrm{E}+05 \mathrm{~g})$ is slated for disposal. Table 1 summarizes waste material types and masses for items in the reactor and not in the reactor. A detailed inventory of items is shown in Appendix A and Appendix B. Carbon steel is listed in the storage can and pool waste. However, none of the carbon steel waste was in the reactor to be activated. These items only have radioactive activity due to contamination on their surfaces (which is primarily Co-60). This activity is accounted for in the dose-to-curie model resulting in a slight overestimation of the total activity as it adds to the Co-60 activity.

Table 1: Waste Material Summary

\begin{tabular}{|c|c|c|c|c|}
\hline Waste Location & In Reactor & $\begin{array}{l}\text { Aluminum Mass } \\
\text { Pounds (g) }\end{array}$ & $\begin{array}{l}\text { Steel Mass } \\
\text { Pounds (g) }\end{array}$ & $\begin{array}{l}\text { Total Mass } \\
\text { Pounds (g) }\end{array}$ \\
\hline \multirow{3}{*}{ Storage Can } & Yes & $\begin{array}{c}135.85 \\
(6.1621 E+04)\end{array}$ & $\begin{array}{c}94.00 \\
(4.2638 \mathrm{E}+04)\end{array}$ & $\begin{array}{c}229.85 \\
(1.0426 \mathrm{E}+05)\end{array}$ \\
\hline & No & 0 & $\begin{array}{c}14.00 \\
(6.350 \mathrm{E}+03)\end{array}$ & $\begin{array}{c}13.80 \\
(6.260 \mathrm{E}+03)\end{array}$ \\
\hline & Sub Total & $\begin{array}{c}135.85 \\
(6.1621 \mathrm{E}+04)\end{array}$ & $\begin{array}{c}108.00 \\
(4.8988 \mathrm{E}+04)\end{array}$ & $\begin{array}{c}243.85 \\
(1.1061 \mathrm{E}+05)\end{array}$ \\
\hline \multirow{3}{*}{ Pool } & Yes & $82.00(3.7195 \mathrm{E}+04)$ & $\begin{array}{c}142.00 \\
(6.4410 E+04)\end{array}$ & $\begin{array}{c}224.00 \\
(1.0160 \mathrm{E}+04)\end{array}$ \\
\hline & No & $\begin{array}{c}9.24 \\
(4.19 E+03)\end{array}$ & $\begin{array}{c}7.50 \\
(3.40 E+03)\end{array}$ & $\begin{array}{c}16.74 \\
(7.593 \mathrm{E}+03)\end{array}$ \\
\hline & Sub Total & $\begin{array}{c}91.24 \\
(4.1386 E+04)\end{array}$ & $\begin{array}{c}149.50 \\
(6.7812 E+04)\end{array}$ & $\begin{array}{c}260.74 \\
(1.0920 E+05)\end{array}$ \\
\hline \multicolumn{2}{|r|}{ Grand Total } & $\begin{array}{c}227.09 \\
(1.0301 E+05)\end{array}$ & $\begin{array}{c}257.50 \\
(1.1680 E+05)\end{array}$ & $\begin{array}{c}484.59 \\
(2.1981 E+05)\end{array}$ \\
\hline
\end{tabular}

\section{CHARACTERIZATION}

\subsection{ACTIVATION PRODUCTS}

As part of characterization methodology for the beryllium cage using computer modeling, activation products and concentrations in curies $(\mathrm{Ci})$ per $\mathrm{cm}^{3}$ for 6061 aluminum and 304 stainless steel were determined and shown in Table 2 and Table 3 (Navarro, et al. 2021). This modeling resulted in conservative estimates for radionuclide concentrations since it was based on activation in a maximum flux zone (i.e., reactor midplane) at the outer edge of the beryllium reflector. Further discussion of the impact of neutron flux is contained in section 5.2. 
Table 2. (100\%) Aluminum Isotopic Distribution for Cage Location (Mar-2021)

\begin{tabular}{|c|c|c|}
$\begin{array}{c}\text { Aluminum } \\
\text { Isotopic } \\
\text { Distribution }\end{array}$ & $\mathrm{Ci} / \mathrm{cm}^{3}$ & $\begin{array}{c}\text { Activity } \\
\text { Fraction }\end{array}$ \\
\hline H-3 & $9.45 \mathrm{E}-06$ & $2.29 \mathrm{E}-02$ \\
\hline Al-26 & $9.76 \mathrm{E}-09$ & $2.37 \mathrm{E}-05$ \\
\hline Si-32 & $3.97 \mathrm{E}-11$ & $9.62 \mathrm{E}-08$ \\
\hline P-32 & $3.97 \mathrm{E}-11$ & $9.62 \mathrm{E}-08$ \\
\hline Fe-55 & $1.77 \mathrm{E}-04$ & $4.29 \mathrm{E}-01$ \\
\hline Fe-60 & $3.88 \mathrm{E}-10$ & $9.40 \mathrm{E}-07$ \\
\hline Co-60 & $2.24 \mathrm{E}-04$ & $5.43 \mathrm{E}-01$ \\
\hline Co-60m & $3.88 \mathrm{E}-10$ & $9.40 \mathrm{E}-07$ \\
\hline Ni-63 & $2.11 \mathrm{E}-06$ & $5.11 \mathrm{E}-03$ \\
\hline Zn-65 & $2.71 \mathrm{E}-11$ & $6.57 \mathrm{E}-08$ \\
\hline Total & $\mathbf{4 . 1 3 E}-04$ & \\
\hline
\end{tabular}

Table 3. (100\%) Stainless Steel Isotopic Distribution for Cage Location (Mar-2021)

\begin{tabular}{|c|c|c|}
$\begin{array}{c}\text { 304 Stainless } \\
\text { Steel Isotopic } \\
\text { Distribution }\end{array}$ & $\begin{array}{c}\text { Ci/cm } \\
\text { H-3 }\end{array}$ & $\begin{array}{c}\text { Activity } \\
\text { Fraction }\end{array}$ \\
\hline C-14 & $1.46 \mathrm{E}-06$ & $3.44 \mathrm{E}-06$ \\
\hline Fe-55 & $1.22 \mathrm{E}-08$ & $1.21 \mathrm{E}-08$ \\
\hline Co-60 & $1.32 \mathrm{E}-01$ & $5.29 \mathrm{E}-01$ \\
\hline $\mathbf{N i}-5 \mathbf{5}$ & $1.12 \mathrm{E}-02$ & $1.11 \mathrm{E}-02$ \\
\hline $\mathbf{N i}-63$ & $\mathbf{1 . 6 6 \mathrm { E } - 0 3}$ & $1.65 \mathrm{E}-03$ \\
\hline Total & $\mathbf{4 . 6 1 \mathrm { E } - 0 1}$ & $4.58 \mathrm{E}-01$ \\
\hline
\end{tabular}

These distributions show most of the radionuclides other than Co-60 are beta emitters or low energy gamma emitters that are hard to detect with the detector used for the survey. Therefore, the dose-tocurie model will be used to estimate the Co-60 activity and the distributions used to determine the total activity and the resultant activities for each nuclide.

The waste does contain steels other than 304 stainless steels, but the steel items that were in the reactor are all 300 series stainless or have very similar composition to 304 stainless steel meaning the activation products for 304 stainless steel are appropriate for characterization of all the steels in the waste stream.

To establish the overall radionuclide fractions for the waste, the relative volumes of aluminum and stainless steel must be determined. Since the mass of the in-reactor items was measured, the volumes and relative volumetric fractions can be determined by multiplying the mass by the density of aluminum $\left(2.7 \mathrm{~g} / \mathrm{cm}^{3}\right)$ and steel $\left(8.0 \mathrm{~g} / \mathrm{cm}^{3}\right)$. For items in the storage can, this results in an in-reactor waste volume of $2.3 \mathrm{E}+04 \mathrm{~cm}^{3}$ of aluminum and $5.3 \mathrm{E}+03 \mathrm{~cm}^{3}$ of steel for a relative volumetric fraction of 0.81 for aluminum and 0.19 for steel. For the waste items not in the storage can, the in-reactor waste volume is $1.4 \mathrm{E}+04 \mathrm{~cm}^{3}$ of aluminum and $8.1 \mathrm{E}+03 \mathrm{~cm}^{3}$ of steel for a relative volumetric fraction of 0.63 for aluminum and 0.37 for steel (See Table 4 and Table 5.) 
Table 4: Storage Can In-Reactor Waste

\begin{tabular}{|l|r|r|}
\hline \multicolumn{3}{|c|}{ In-Reactor Waste Items - Storage Can } \\
\hline & Aluminum & \multicolumn{1}{c|}{ Steel } \\
\hline mass (lbs) & 135.85 & 94.00 \\
\hline mass (g) & $6.1621 \mathrm{E}+04$ & $4.2638 \mathrm{E}+04$ \\
\hline mass fraction & $5.9052 \mathrm{E}-01$ & $4.0896 \mathrm{E}-01$ \\
\hline Density $\left(\mathbf{g} / \mathbf{c m}^{\mathbf{3}}\right.$ ) & 2.7 & 8.0 \\
\hline Volume $\left(\mathbf{c m}^{\mathbf{3}}\right)$ & $2.3 \mathrm{E}+04$ & $5.3 \mathrm{E}+03$ \\
\hline Volume fraction & $\mathbf{0 . 8 1}$ & $\mathbf{0 . 1 9}$ \\
\hline
\end{tabular}

Table 5: Pool In-Reactor Waste

\begin{tabular}{|l|r|r|}
\hline \multicolumn{3}{|c|}{ In-Reactor Waste Items - Pool } \\
\hline mass $(\mathbf{l b s})$ & \multicolumn{1}{|c|}{ Aluminum } & \multicolumn{1}{c|}{ Steel } \\
\hline mass $\mathbf{( g )}$ & 82.00 & 142.00 \\
\hline mass fraction & $3.7195 \mathrm{E}+04$ & $6.4410 \mathrm{E}+04$ \\
\hline Density $\left(\mathbf{g} / \mathbf{c m}^{3}\right)$ & 0.366071 & 0.633929 \\
\hline Volume $\left(\mathbf{c m}^{\mathbf{3}}\right)$ & 2.7 & 8.0 \\
\hline Volume fraction & $1.4 \mathrm{E}+04$ & $8.1 \mathrm{E}+03$ \\
\hline
\end{tabular}

Based on these volume fractions, the radionuclide mix can then be determined for the waste in the storage can and for the waste in the pool.

Table 6: Radionuclide Fractions Waste in Storage Can

\begin{tabular}{|c|c|c|c|c|}
\hline Radionuclide & $\begin{array}{c}\text { Aluminum Nuclide } \\
\text { Concentration at } 0.81 \\
\text { Volumetric Fraction } \\
\text { (Ci/cm3) }\end{array}$ & $\begin{array}{c}\text { Steel Nuclide } \\
\text { Concentration at } \\
0.19 \text { Volumetric } \\
\text { Fraction }(\mathrm{Ci} / \mathrm{cm} 3)\end{array}$ & $\begin{array}{c}\text { Nuclide } \\
\text { Concentration } \\
\text { for Mixture } \\
(\mathrm{Ci} / \mathrm{cm} 3)\end{array}$ & $\begin{array}{l}\text { Nuclide } \\
\text { Activity } \\
\text { Fraction }\end{array}$ \\
\hline $\mathrm{H}-3$ & 7.65E-06 & $6.57 \mathrm{E}-07$ & $8.31 \mathrm{E}-06$ & 4.34E-05 \\
\hline C-14 & $0.00 \mathrm{E}+00$ & 2.32E-09 & 2.32E-09 & $1.21 \mathrm{E}-08$ \\
\hline Al-26 & 7.91E-09 & $0.00 \mathrm{E}+00$ & 7.91E-09 & 4.13E-08 \\
\hline Si-32 & $3.22 \mathrm{E}-11$ & $0.00 \mathrm{E}+00$ & $3.22 \mathrm{E}-11$ & $1.68 \mathrm{E}-10$ \\
\hline P-32 & $3.22 \mathrm{E}-11$ & $0.00 \mathrm{E}+00$ & $3.22 \mathrm{E}-11$ & $1.68 \mathrm{E}-10$ \\
\hline Fe-55 & $1.43 \mathrm{E}-04$ & $1.01 \mathrm{E}-01$ & $1.01 \mathrm{E}-01$ & 5.29E-01 \\
\hline Fe-60 & $3.14 \mathrm{E}-10$ & $0.00 \mathrm{E}+00$ & $3.14 \mathrm{E}-10$ & $1.64 \mathrm{E}-09$ \\
\hline Co-60 & $1.81 \mathrm{E}-04$ & $2.13 \mathrm{E}-03$ & $2.31 \mathrm{E}-03$ & $1.21 \mathrm{E}-02$ \\
\hline Co-60m & $3.14 \mathrm{E}-10$ & $0.00 \mathrm{E}+00$ & $3.14 \mathrm{E}-10$ & $1.64 \mathrm{E}-09$ \\
\hline Ni-59 & $0.00 \mathrm{E}+00$ & $3.15 E-04$ & $3.15 E-04$ & $1.65 \mathrm{E}-03$ \\
\hline $\mathrm{Ni}-63$ & $1.71 \mathrm{E}-06$ & $8.76 \mathrm{E}-02$ & $8.76 \mathrm{E}-02$ & $4.58 \mathrm{E}-01$ \\
\hline$Z n-65$ & $2.20 \mathrm{E}-11$ & $0.00 \mathrm{E}+00$ & $2.20 \mathrm{E}-11$ & $1.15 \mathrm{E}-10$ \\
\hline \multicolumn{3}{|r|}{ Total Ci/cm3 } & 1.91E-01 & \\
\hline
\end{tabular}


Table 7: Radionuclide Fractions Waste in Pool

\begin{tabular}{|c|c|c|c|c|}
\hline Radionuclide & $\begin{array}{c}\text { Aluminum Nuclide } \\
\text { Concentration at } 0.63 \\
\text { Volumetric Fraction } \\
\text { (Ci/cm3) }\end{array}$ & $\begin{array}{c}\text { Steel Nuclide } \\
\text { Concentration at } 0.37 \\
\text { Volumetric Fraction } \\
(\mathrm{Ci} / \mathrm{cm} 3)\end{array}$ & $\begin{array}{c}\text { Nuclide } \\
\text { Concentration } \\
\text { for Mixture } \\
(\mathrm{Ci} / \mathrm{cm} 3)\end{array}$ & $\begin{array}{l}\text { Nuclide } \\
\text { Activity } \\
\text { Fraction }\end{array}$ \\
\hline $\mathrm{H}-3$ & 5.95E-06 & $1.28 \mathrm{E}-06$ & 7.23E-06 & $1.94 \mathrm{E}-05$ \\
\hline C-14 & $0.00 \mathrm{E}+00$ & 4.51E-09 & 4.51E-09 & $1.21 \mathrm{E}-08$ \\
\hline Al-26 & 6.15E-09 & $0.00 E+00$ & $6.15 E-09$ & $1.65 \mathrm{E}-08$ \\
\hline Si-32 & $2.50 \mathrm{E}-11$ & $0.00 \mathrm{E}+00$ & $2.50 \mathrm{E}-11$ & $6.72 \mathrm{E}-11$ \\
\hline P-32 & $2.50 \mathrm{E}-11$ & $0.00 \mathrm{E}+00$ & $2.50 \mathrm{E}-11$ & $6.72 \mathrm{E}-11$ \\
\hline Fe-55 & $1.12 \mathrm{E}-04$ & 1.97E-01 & 1.97E-01 & 5.29E-01 \\
\hline Fe-60 & $2.44 \mathrm{E}-10$ & $0.00 E+00$ & 2.44E-10 & $6.56 \mathrm{E}-10$ \\
\hline Co-60 & $1.41 \mathrm{E}-04$ & 4.14E-03 & 4.29E-03 & 1.15E-02 \\
\hline Co-60m & $2.44 \mathrm{E}-10$ & $0.00 E+00$ & $2.44 \mathrm{E}-10$ & $6.56 \mathrm{E}-10$ \\
\hline Ni-59 & $0.00 \mathrm{E}+00$ & $6.14 \mathrm{E}-04$ & $6.14 \mathrm{E}-04$ & $1.65 \mathrm{E}-03$ \\
\hline $\mathrm{Ni}-63$ & $1.33 \mathrm{E}-06$ & $1.71 \mathrm{E}-01$ & 1.71E-01 & $4.58 \mathrm{E}-01$ \\
\hline$Z n-65$ & $1.71 \mathrm{E}-11$ & $0.00 \mathrm{E}+00$ & $1.71 \mathrm{E}-11$ & $4.58 \mathrm{E}-11$ \\
\hline \multicolumn{3}{|r|}{ Total $\mathrm{Ci} / \mathrm{cm} 3$} & 3.72E-01 & \\
\hline
\end{tabular}

\subsection{MICROSHIELD ANALYSIS DESCRIPTION AND METHODOLOGY}

A model of the of the storage can was developed and analyzed using MicroShield ${ }^{\mathrm{TM}} \mathrm{V}$ 8.03. This model was developed to closely approximate the storage can waste geometry, physical characteristics, and exposure rate profile. The model is used to estimate the expected exposure rate from $1 \mathrm{Ci}$ of $\mathrm{Co}-60$. Based on the modeled exposure rate and the measured exposure rate from the survey results, the amount of Co-60 activity of the storage can then be estimated. Once the Co-60 activity is estimated, the other radionuclides are then scaled based on the isotopic distributions from Section 4.1 to determine the overall activity for each radionuclide. This is known as a "dose-to-curie" methodology. Even though the model is designed to closely approximate the actual storage can, conservatism is built in to slightly overestimate the curie content.

\subsection{STORAGE CAN SURVEY DATA}

In-air surveys of the can were conducted on 6/17/2020, this survey (Ellis June 16, 2020) consisted of 27 measurements taken at four different heights from the bottom of the storage can (See Figure 1: Storage Can Survey Data from HFIR-537801). The mean, median and maximum exposure rates for each survey elevation (dose point) was determined. The survey data is tabularized and shown in Table 8: Storage Can Survey Data Table. It should be noted that several "on contact" measurements were also taken. These were not used in developing the model since on-contact dose rates are particularly sensitive to the distance the measurement is taken. However, these on-contact measurements were used to assist in evaluating the model after it was developed and discussed further in Section 5. 
Figure 1: Storage Can Survey Data from HFIR-537801

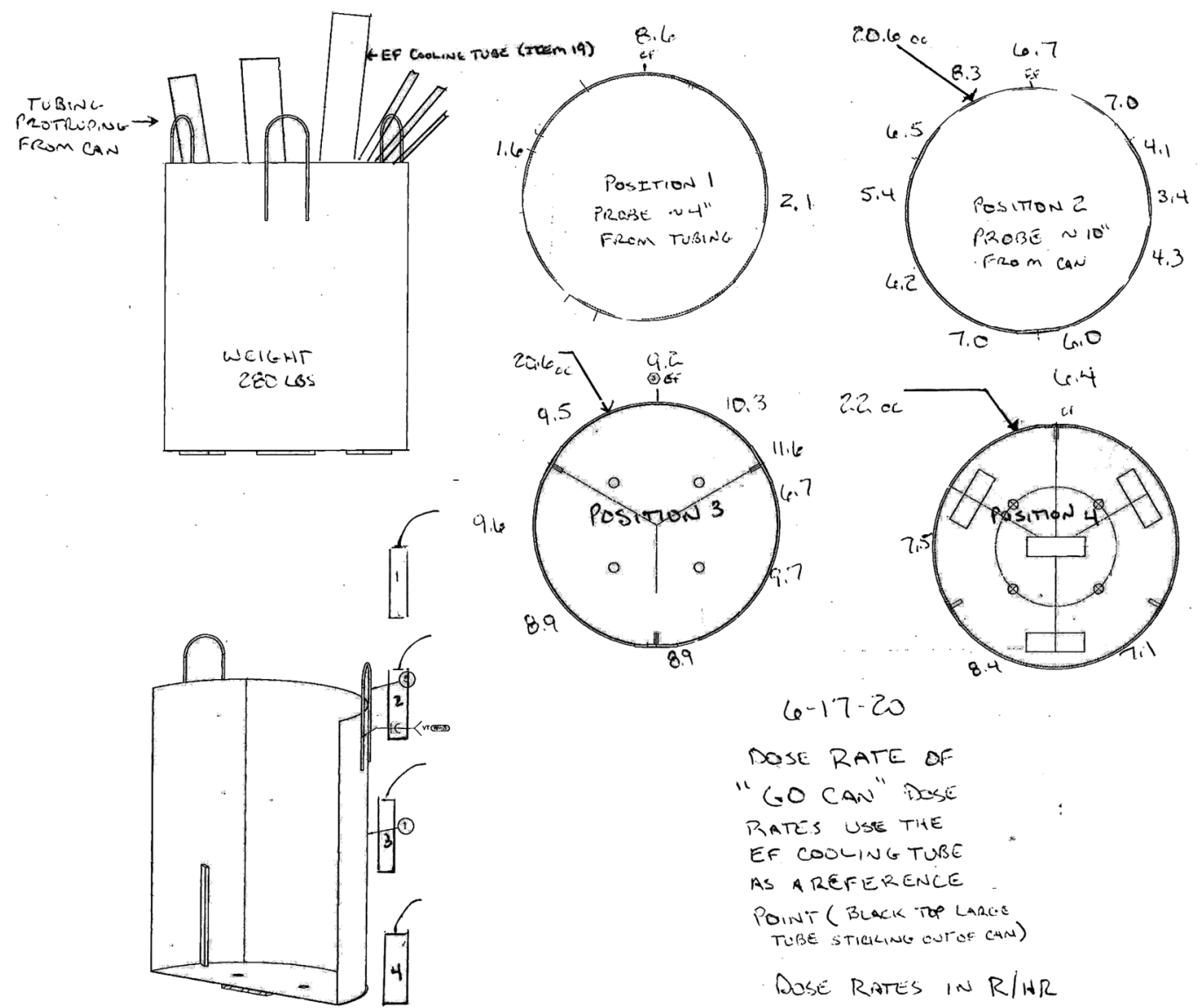

Table 8: Storage Can Survey Data Table

\begin{tabular}{|r|r|r|r|r|}
\hline \multicolumn{1}{|c|}{$\begin{array}{c}\text { Survey } \\
\text { Point }\end{array}$} & DP1 & DP2 & DP3 & DP4 \\
\hline $\mathbf{1}$ & 8600 & 6700 & 9200 & 6400 \\
\hline $\mathbf{2}$ & & 7000 & 10300 & \\
\hline $\mathbf{3}$ & & 4100 & 11600 & \\
\hline $\mathbf{4}$ & 2100 & 3400 & 6700 & \\
\hline $\mathbf{5}$ & & 4300 & 9700 & 7100 \\
\hline $\mathbf{6}$ & & 6000 & 8900 & \\
\hline $\mathbf{7}$ & & 7000 & 8900 & 8400 \\
\hline $\mathbf{8}$ & & 6200 & & \\
\hline $\mathbf{9}$ & & 5400 & 9600 & 7500 \\
\hline $\mathbf{1 0}$ & 1600 & 6500 & & \\
\hline 11 & & 8300 & 9500 & \\
\hline Mean & 4100 & $\mathbf{5 9 0 0}$ & $\mathbf{9 3 7 8}$ & $\mathbf{7 3 5 0}$ \\
\hline Median & $\mathbf{2 1 0 0}$ & $\mathbf{6 2 0 0}$ & $\mathbf{9 5 0 0}$ & $\mathbf{7 3 0 0}$ \\
\hline Max & $\mathbf{8 6 0 0}$ & $\mathbf{8 3 0 0}$ & $\mathbf{1 1 6 0 0}$ & $\mathbf{8 4 0 0}$ \\
\hline
\end{tabular}




\subsection{MICROSHIELD MODEL}

\subsubsection{Storage Can Geometry}

The dimensions of the storage can are based on current facility drawings (UT-Battelle, Oak Ridge National Laboratory January 4, 2018). The storage can was modeled in MicroShield as a right circular cylinder with an outside radius of 12.625 inches $(32.0675 \mathrm{~cm})$, and a height of 30.125 inches $(76.5175 \mathrm{~cm}$.) The storage can wall was 14-gauge steel with a thickness of 0.078125 inches $(0.198438 \mathrm{~cm})$ from 15 U.S.C. $\$ 206$ resulting in a source radius of 12.54688 inches $(31.86906 \mathrm{~cm})$. The modeled source volume is $2.4415 \mathrm{E}+05 \mathrm{~cm}^{3}$.

\subsubsection{Materials and Effective Density}

Each piece placed in the storage can was weighed and their mass determined (Table 1). From the source volume calculated above, the relative density for aluminum and steel mixture can thus be determined by dividing their respective masses by the source volume. This method is consistent with the material mixture specification instructions included in the MicroShield User's Manual (Grove Software, Inc. 1992). The source specification based on these masses and volume is an aluminum density of $2.5239 \mathrm{E}-01 \mathrm{~g} / \mathrm{cm}^{3}$ and $1.7501 \mathrm{E}-01 \mathrm{~g} / \mathrm{cm}^{3}$ for iron. The density of the wall cladding was $8.0 \mathrm{~g} / \mathrm{cm}^{3}$ iron. Iron was used as the surrogate material for stainless steel in MicroShield as it is a built-in material which very closely approximates the shielding characteristics of both stainless and carbon steels.

\subsubsection{Source Term}

The source used for the model was assumed to be $1 \mathrm{Ci}(3.7 \mathrm{E} 10 \mathrm{~Bq})$ of Co-60. This is based on the isotopic distribution from Table 6 and Table 7. This distribution shows most of the radionuclides other than Co-60 are beta emitters or low energy gamma emitters that are hard to detect with the detector used for the survey. Therefore, the exposure rate from the storage can is conservatively assumed to be solely from $\mathrm{Co}-60$ photons. Use of $1 \mathrm{Ci}$ as the activity allows for scaling the activity with the empirical measurements to estimate the Co- 60 activity at the time of the survey and therefore the total radionuclide inventory.

\subsubsection{Dose Point Location}

During the survey of the cage, the positions the detector was placed from storage container was as follows: dose point 1 was approximately 4" from the tubing that extended approximately 24" above the storage can; dose point 2 was approximately 10 inches at the top of the storage can; dose point 3 was centered between the top and bottom of the storage can at approximately 10 inches away; and dose point 4 was near the bottom of the storage can approximately 10 inches away. Based on the survey measurement locations, the dose points for the MicroShield model are selected as follows: Dose point 1 is 4 inches $(10.16 \mathrm{~cm})$ from the side of the can $(42.228 \mathrm{~cm}$ from the center vertical axis) at a height of 54.125 inches $(137.478 \mathrm{~cm})$ from the bottom. Dose Point 2 through 4 are 10 inches $(25.4 \mathrm{~cm})$ from the side of the storage can $(57.468 \mathrm{~cm}$ from the center vertical axis) at $82.518 \mathrm{~cm}, 38.735 \mathrm{~cm}$, and $4.0 \mathrm{~cm}$ from the bottom. Additionally, an "oncontact" dose point was used for further evaluation of the model. This dose point coincided with the dose point 3 height but is 1 inch $(2.54 \mathrm{~cm})$ from the side at $38.735 \mathrm{~cm}$ from the vertical axis of the storage can. 


\subsubsection{MicroShield Results}

The MicroShield model resulted in the exposure rates for $1 \mathrm{Ci}$ of Co-60 as shown in Table 9 (See Appendix C).

Table 9: MicroShield Results for $1 \mathrm{Ci}$ Co-60

\begin{tabular}{|l|l|c|}
\hline Dose Point & Description & $\begin{array}{c}\text { Exposure Rate } \\
\left(\mathbf{m} \mathbf{~ h}^{-1} \mathbf{C i}^{-\mathbf{1}}\right)\end{array}$ \\
\hline DP-1 & 4" from side above storage can & 907.4 \\
\hline DP-2 & Top of storage can 10" from side & 2032 \\
\hline DP-3 & Middle of storage can 10" from side & 3082 \\
\hline DP-4 & Bottom of storage can 10" from side & 2383 \\
\hline DP-5 & Middle of storage can 1" from side & 8612 \\
\hline
\end{tabular}

\section{CALCULATION AND EVALUATION OF MODEL RESULTS}

\subsection{ACTIVITY ESTIMATION}

Using the median exposure rate from the survey for dose point 3 of $9500 \mathrm{mR} \mathrm{h}^{-1}$ and the corresponding model exposure rate of $3082 \mathrm{mR} \mathrm{h}^{-1} \mathrm{Ci}^{-1}$, the Co-60 activity can be estimated to be $3.082 \mathrm{Ci}$ (Equation 1). The median exposure rate from the survey data was used to result in a conservative activity estimation. It also resulted in a closer agreement with dose points 2 and 4.

\section{Equation 1: Activity Estimation using Dose-to-Curie}

$$
A=\frac{9500 m R h^{-1}}{3082 m R h^{-1} C i^{-1}}=3.082 \mathrm{Ci} \mathrm{Co}-60
$$

Using this estimate, a comparison of the survey dose profile and model dose profile for all four dose points can be generated. As can be seen in Table 10 and Figure 2, the model closely approximates the survey median and average exposure rates at the dose points except for dose point 1 and is conservative for dose points 2 through 4 . Since the survey at dose point 1 was taken very close to tubing protruding from the top of the storage can, an additional model was created to adjust the activity estimation for this tubing.

Additionally, the model indicates that at $3.082 \mathrm{Ci} \mathrm{Co}-60$, the exposure rate on contact with the storage can at dose point 3 would be $2.654 \mathrm{E}+04 \mathrm{mR} / \mathrm{h}$ compared to the on-contact survey result of $2.06 \mathrm{E}+04 \mathrm{mR} / \mathrm{h}$. This further validates the activity derived from the storage can model is realistic but conservative as far as the waste contained within the storage can. 
Table 10: Model vs Survey Data at 3.082 Ci Co-60

\begin{tabular}{|c|c|c|c|c|}
\hline $\begin{array}{l}\text { Dose } \\
\text { Point }\end{array}$ & Description & $\begin{array}{c}\text { Survey } \\
\text { Average } \\
\text { Exposure } \\
\text { Rate }\left(\mathrm{mR} \mathrm{h}^{-1}\right)\end{array}$ & $\begin{array}{l}\text { Survey } \\
\text { Median } \\
\text { Exposure } \\
\text { Rate (mR } \mathrm{h}^{-} \\
{ }^{1} \text { ) }\end{array}$ & $\begin{array}{c}\text { Modeled } \\
\text { Exposure Rate } \\
\text { at } 3.082 \mathrm{Ci} \\
\left.(\mathrm{mR} \mathrm{h})^{-1}\right)\end{array}$ \\
\hline DP-1 & 4" from Side Above Storage Can & 4100 & 2100 & 2797 \\
\hline DP-2 & Top of Storage Can 10" from side & 5900 & 6200 & 6263 \\
\hline DP-3 & Middle of Storage Can $10^{\prime \prime}$ from side & 9378 & 9500 & 9500 \\
\hline DP-4 & Bottom of Storage Can 10 " from side & 7350 & 7300 & 7345 \\
\hline
\end{tabular}

Figure 2: MicroShield Model and Survey Data Comparison at 3.082 Ci of Co-60

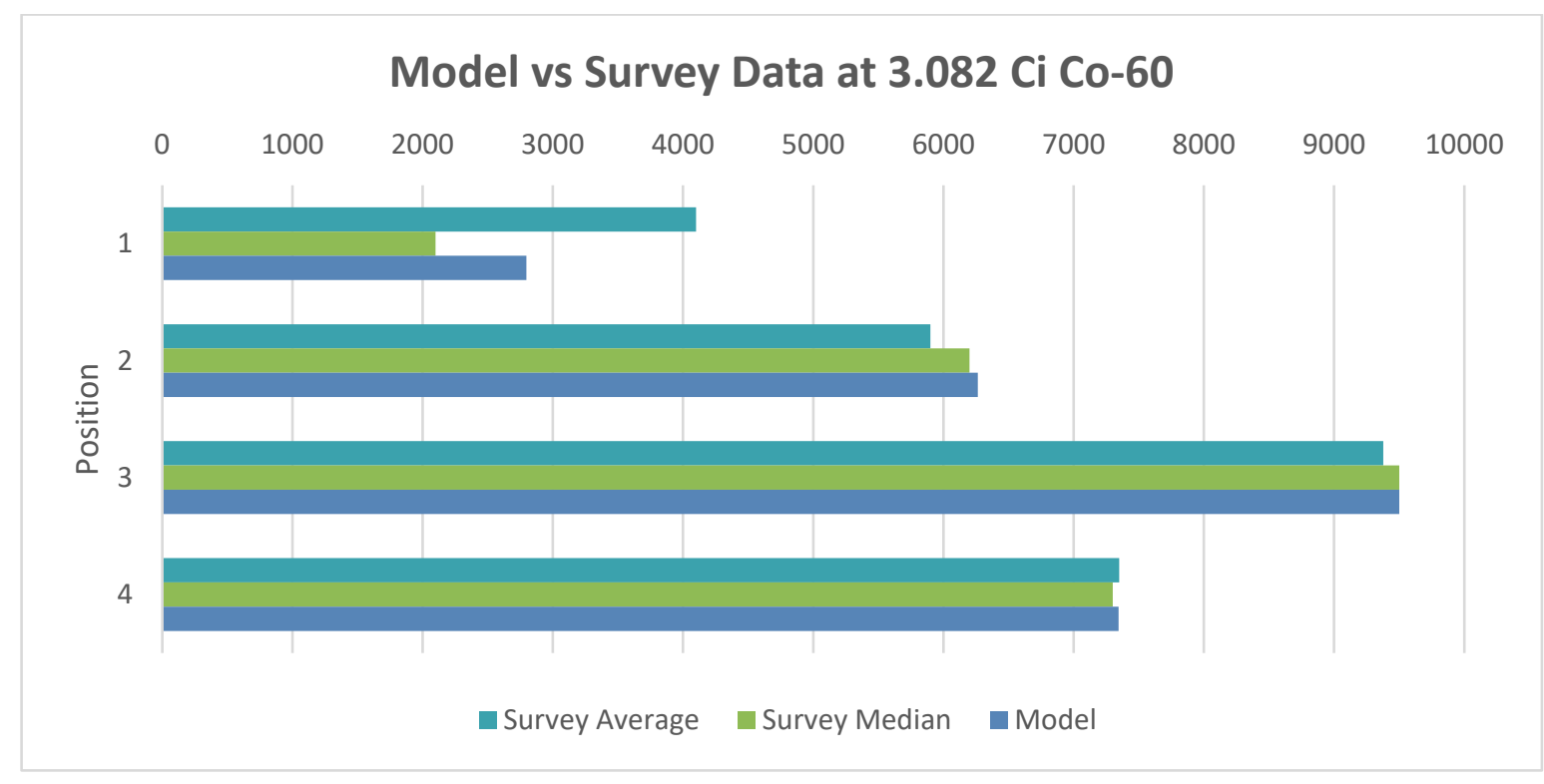

\subsubsection{Additional Experiment Facility Tubing Model}

Some of the waste, primarily tubing, extended above the storage can. Since the estimated exposure rate at dose point 1 for the model at 3.082 $\mathrm{Ci}$ was less than the survey average exposure rate, an additional model for a tube protruding from the storage can was created. According to the survey data, the maximum dose rate at that location coincided with the Engineering Facility Tube Cooling Water Guide Sleeve segment (EF Tube). According to engineering drawings (Union Carbide Nuclear Company, Oak Ridge National Laboratory November 15, 1983), this tube had a maximum inside diameter of 4.625 inches $(11.7475 \mathrm{~cm})$ and a wall thickness of 0.094 inches $(0.23876 \mathrm{~cm})$. The survey indicated that the exposure rate was taken 4 inches $(10.16 \mathrm{~cm})$ from the tubing. For this dose point, there were three measurements, one at the EF Tube and two approximately 90 degrees from the tube.

Therefore, an annular cylinder with inner source radius of 2.3125 inches $(5.87375 \mathrm{~cm})$ and a thickness of 0.094 inches $(0.23876 \mathrm{~cm})$ with a length of 24 inches $(60.96 \mathrm{~cm})$ was modeled. The dose point was placed 4 inches from the wall (6.4065 inches from the vertical axis) at the end of 
the tubing. This vertical position is worse case since it would result in a lower exposure rate per curie. To model a 90-degree rotation, dose point 2 was modeled at 19.5143 inches (49.56635 $\mathrm{cm}$ ) from the vertical axis of the EF tube (See Figure 3). Since this would also affect the modeled dose rates at dose points 2 through 4 for the storage can. These were modeled (dose points 3 through 5) at 10 inches from the wall (12.065 inches from the vertical centerline).

\section{Figure 3: EF Tubing Model Dose Points (Plan View in inches)}

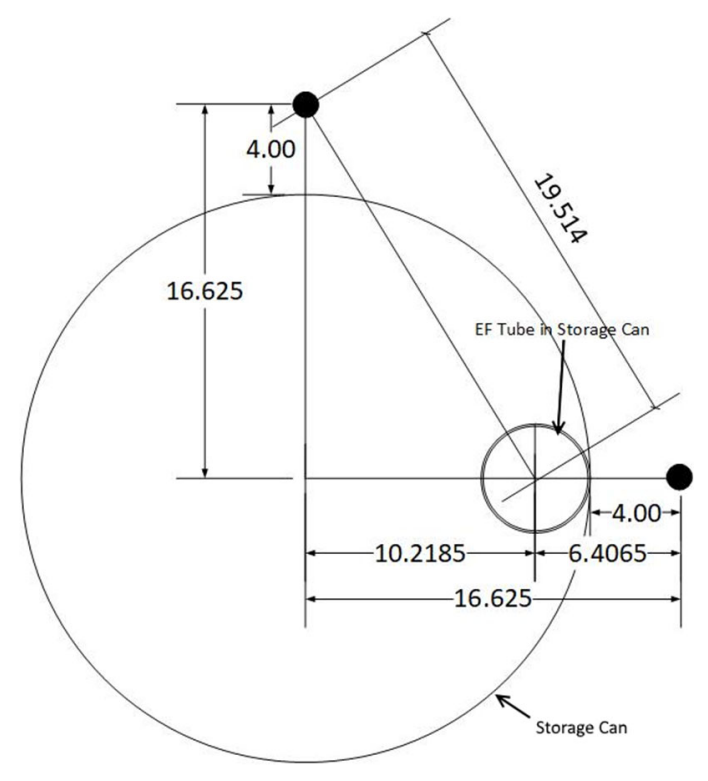

\subsubsection{Adjusted Activity for EF Tubing}

The EF tubing model resulted in the exposure rates per curie of Co-60 as shown in Table 11.

Table 11: EF Tube Model Exposure Rate $\left(\mathrm{mR} \mathrm{h}^{-1} \mathbf{C i}^{-1}\right)$

\begin{tabular}{|l|l|c|}
$\begin{array}{l}\text { Dose } \\
\text { Point }\end{array}$ & Description & $\begin{array}{l}\text { Exposure } \\
\text { Rate } \\
\left(\mathbf{m R ~ h} \mathbf{~}^{-1} \mathbf{C i}^{-1} \mathbf{)}\right.\end{array}$ \\
\hline EF-DP-1 & 4" from end of EF Tube & $1.51 \mathrm{E}+04$ \\
\hline EF-DP-2 & $\begin{array}{l}\text { 19.5143" from the end of EF tube } \\
\text { (90-degree rotation) }\end{array}$ & $3.51 \mathrm{E}+03$ \\
\hline EF-DP-3 & 10" from EF Tube at DP-2 & $6.68 \mathrm{E}+03$ \\
\hline EF-DP-4 & 10" from EF Tube at DP-3 & $2.11 \mathrm{E}+03$ \\
\hline EF-DP-5 & 10" from EF Tube at DP-4 & $8.31 \mathrm{E}+02$ \\
\hline
\end{tabular}

Using the maximum dose rate for DP-1 of $8600 \mathrm{mR} / \mathrm{h}$ minus the estimated dose rate of 2797 $\mathrm{mR} / \mathrm{h}$ at that location from $3.082 \mathrm{Ci}$ of $\mathrm{Co}-60$ in the storage can, we can estimate the additional Co-60 activity from the EF tube (Equation 2.) 


\section{Equation 2: EF Tube Activity Estimation}

$$
A=\frac{(8600-2797) m R h^{-1}}{1.512 E+04 m R h^{-1} C i^{-1}}=0.384 C i C o-60
$$

Using this estimate, we can determine the total exposure rate from the storage can at $3.466 \mathrm{Ci}$ (3.082 $\mathrm{Ci}$ for the storage can plus $0.384 \mathrm{Ci}$ from the tube) and the maximum exposure rate at each of the dose point locations. These are shown in Table 12. The 90-degree rotation dose rates at this activity also shows it to be very conservative. The comparison from the modeled exposure rates at $3.466 \mathrm{Ci}$ to actual measurements shows the models to be conservative.

Table 12: Exposure Rates for Adjusted Co-60 Activity of 3.466 Ci

\begin{tabular}{|c|c|c|c|c|c|}
\hline $\begin{array}{l}\text { Dose } \\
\text { Point }\end{array}$ & Description & $\begin{array}{l}\text { From 3.082 } \\
\text { Ci Co-60 in } \\
\text { Storage Can } \\
(\mathrm{mR} / \mathrm{h})\end{array}$ & $\begin{array}{c}\text { From } 0.384 \\
\text { Ci from EF } \\
\text { Tube Above } \\
\text { Storage Can } \\
(\mathrm{mR} / \mathrm{h})\end{array}$ & $\begin{array}{c}\text { Total } \\
\text { Exposure } \\
\text { Rate from } \\
\text { model } \\
(\mathrm{mR} / \mathrm{h})\end{array}$ & $\begin{array}{l}\text { Corresponding } \\
\text { Measured } \\
\text { Exposure Rate } \\
(\mathrm{mR} / \mathrm{h})\end{array}$ \\
\hline DP-1 & At EF tube top & 2797 & 5803 & 8600 & 8600 \\
\hline DP-1 & $\begin{array}{l}\text { 90-degrees from } \\
\text { EF Tube }\end{array}$ & 2797 & 1346 & 4143 & 1600,2100 \\
\hline DP-2 & $\begin{array}{l}\text { At top of Storage } \\
\text { Can }\end{array}$ & 6263 & 2565 & $8829 *$ & 6700 \\
\hline DP-3 & $\begin{array}{l}\text { Middle of Storage } \\
\text { Can }\end{array}$ & 9500 & 808.7 & $10310^{*}$ & 9200 \\
\hline DP-4 & $\begin{array}{l}\text { Bottom of } \\
\text { Storage Can }\end{array}$ & 7345 & 318.9 & $7664 *$ & Not Taken** \\
\hline
\end{tabular}

\subsubsection{Decay Correction}

The survey was conducted on 6/17/2020, however the radionuclide distributions were decay corrected for $3 / 06 / 2021$. To use the radionuclide distributions, the Co- 60 activity must be decay corrected to $3 / 06 / 2021$. The half-life of Co-60 is 5.2713 years (ICRP-107) and the decay time is 0.717 years. This results in a decay corrected Co-60 activity of $3.154 \mathrm{Ci}$ on 3/06/2021 (Equation 3.)

\section{Equation 3: Decay Correction Equation}

$$
A_{t}=A_{0} e^{-\lambda t}=3.466 C i e^{-\left(\frac{\ln (2)}{5.2713 y}\right) 0.7173 y}=3.154 C i C o-60
$$

\subsubsection{Pool Waste Activity Estimation}

Assuming the waste in the storage can and the waste outside the can (pool waste) comes from relatively similar processes, the Co-60 concentrations for aluminum and steel would be similar. In other words, the storage can waste should be a good sample of the entirety of the waste slated for disposal and its activity can be used to infer the activity for all the waste from similar 
processes slated for disposal. Therefore, the pool waste activity can then be conservatively determined using the Co- 60 concentrations for both the aluminum and steel components of the waste in the storage can.

Based on the isotopic distributions assumed for the 0.81 to 0.19 aluminum to steel volumetric ratio (Table 6), $7.86 \%$ of the Co-60 activity comes from aluminum and $92.14 \%$ of the Co-60 activity comes from stainless steel $\left(1.814 \mathrm{E}-04 \mathrm{Ci} \mathrm{cm}^{-3} / 2.309 \mathrm{E}-03 \mathrm{Ci} \mathrm{cm}^{-3}=7.856 \mathrm{E}-02\right.$ for aluminum, and $2.128 \mathrm{E}-03 \mathrm{Ci} \mathrm{cm}^{-3} / 2.309 \mathrm{E}-03 \mathrm{Ci} \mathrm{cm}^{-3}=9.214 \mathrm{E}-01$ for stainless steel). At a Co-60 activity of $3.154 \mathrm{Ci}$, that equates to an activity of $2.478 \mathrm{E}-01 \mathrm{Ci}$ for the aluminum components and $2.906 \mathrm{E}+00 \mathrm{Ci}$ for the stainless steel components. With an in-reactor aluminum volume of $2.282 \mathrm{E}+04 \mathrm{~cm}^{3}$ and steel volume of $5.330 \mathrm{E}+03 \mathrm{~cm}^{3}$ in the storage can, that results in volumetric Co-60 concentrations in the storage can of $1.086 \mathrm{E}-05 \mathrm{Ci} / \mathrm{cm}^{3}$ for aluminum and $5.453 \mathrm{E}-04 \mathrm{Ci} / \mathrm{cm}^{3}$ for stainless steel (Table 13). It should be noted that these concentrations are lower than the modeled concentrations, and are indicative of the model's conservatism (e.g., material modeled in the highest flux region of the reactor.) However, these concentrations are based on actual measurements of the waste in the storage can and represent a better estimate of the activity. A more detailed discussion concerning the impact of neutron flux is included in Section 5.2.

The waste volumes for the pool waste are $1.378 \mathrm{E}+04 \mathrm{~cm}^{3}$ aluminum and $8.051 \mathrm{E}+03 \mathrm{~cm}^{3}$ steel. Using the Co-60 volumetric concentrations from the storage can waste results in an activity of 1.5E-01 $\mathrm{Ci}$ for the aluminum components and $4.4 \mathrm{E}+00 \mathrm{Ci}$ for the steel components with a total of 4.5E+00 Ci Co-60 (See Table 13).

Table 13: Pool Waste Co-60 Activity Calculation

\begin{tabular}{|c|c|c|c|}
\hline & $\begin{array}{l}\text { Aluminu } \\
\mathrm{m}\end{array}$ & Steel & Total \\
\hline $\begin{array}{l}\text { Storage can Co- } 60 \text { activity fraction by material type } \\
\text { (determined from Table } 6 \text { ) }\end{array}$ & $7.856 \mathrm{E}-02$ & $9.214 \mathrm{E}-01$ & $1.000 \mathrm{E}+00$ \\
\hline $\begin{array}{l}\text { Storage can Co- } 60 \text { activity on } 3 / 6 / 21 \\
\text { (Ci from } 5.1 .3 \text { ) }\end{array}$ & $2.48 \mathrm{E}-01$ & $2.91 \mathrm{E}+00$ & $3.154 \mathrm{E}+00$ \\
\hline $\begin{array}{l}\text { In-reactor waste volume in storage can ( } \\
\text { Table 4) }\end{array}$ & $2.282 \mathrm{E}+04$ & $5.330 \mathrm{E}+03$ & $2.815 \mathrm{E}+04$ \\
\hline Storage can waste Co-60 concentration $\left(\mathrm{Ci} / \mathrm{cm}^{3}\right)$ & $5.554 \mathrm{E}-06$ & $5.680 \mathrm{E}-04$ & $1.120 \mathrm{E}-04$ \\
\hline Pool waste volume $\left(\mathrm{cm}^{3}\right)$ & $1.378 \mathrm{E}+04$ & $8.051 \mathrm{E}+03$ & $2.183 \mathrm{E}+04$ \\
\hline Pool waste Co-60 activity on $3 / 6 / 21 *(\mathrm{Ci})$ & 1.5E-01 & $4.4 \mathrm{E}+00$ & $4.5 \mathrm{E}+00$ \\
\hline
\end{tabular}

*All calculations carried through without rounding, final activity reported at 2 significant digits.

\subsubsection{Pool Waste Activity Assessment from On-Contact Exposure Rates}

The author performed an evaluation of Co-60 activity based on underwater on-contact survey measurements taken on the pool waste items during segregation activities. The MicroShield model conservatively assumed a 3" diameter steel rod with a mass of $40 \mathrm{lbs}$. (the maximum mass in the inventory). The on-contact measurement distance was assumed to be 2.5 inches which is very conservative when the actual distance would be with the probe being as close to the material as possible. The estimated exposure rate of $2.331 \mathrm{E}+04 \mathrm{mR} \mathrm{h}^{-1} \mathrm{Ci}^{-1}$ from the MicroShield model 
results in a conservatively estimated Co-60 activity of $3.2 \mathrm{Ci}$. This activity is lower than the 4.5 $\mathrm{Ci}$ estimated from 5.1.4 and provides added confidence that the method used in 5.1.4 is conservative. Additionally, all items had contact dose rate measurement performed underwater (storage can and pool waste items). This information is shown in Appendix A and B. The maximum, average and median dose rates for the storage can exceeds the average underwater on-contact exposure rates for the pool waste items providing additional evidence the estimated activity for the pool waste items is conservative.

\subsubsection{Total Radionuclide Activities}

Using the Co-60 activities from 5.1.3 and 5.1.4, and the radionuclide fractions for the storage can and pool waste in Table 6 and Table 7, the activities for each radionuclide can be determined. These activities are shown in Table 14. The total activity of the reactor waste in the storage can and pool is estimated to be 660 curies.

Table 14: Waste Radionuclide Activities

\begin{tabular}{|c|c|c|c|c|c|}
\hline Radionuclide & $\begin{array}{l}\text { Nuclide activity } \\
\text { fraction } \\
\text { storage can waste } \\
\text { (0.81 aluminum to } \\
0.19 \text { steel } \\
\text { volumetric } \\
\text { fraction) }\end{array}$ & $\begin{array}{l}\text { Nuclide } \\
\text { activity for } \\
\text { storage can } \\
\text { (Ci) }\end{array}$ & $\begin{array}{l}\text { Nuclide activity } \\
\text { fraction } \\
\text { pool waste } \\
\text { ( } 0.68 \text { aluminum } \\
\text { to } 0.32 \text { steel } \\
\text { volumetric } \\
\text { fraction) }\end{array}$ & $\begin{array}{l}\text { Nuclide } \\
\text { activity for } \\
\text { pool waste } \\
\text { (Ci) }\end{array}$ & $\begin{array}{l}\text { Total activity } \\
\text { storage can }+ \\
\text { pool waste } \\
\text { (Ci) }\end{array}$ \\
\hline $\mathrm{H}-3$ & $4.34 \mathrm{E}-05$ & $1.14 \mathrm{E}-02$ & $1.94 \mathrm{E}-05$ & 7.66E-03 & $1.90 \mathrm{E}-02$ \\
\hline C-14 & $1.21 \mathrm{E}-08$ & 3.17E-06 & $1.21 \mathrm{E}-08$ & $4.78 \mathrm{E}-06$ & 7.95E-06 \\
\hline Al-26 & $4.13 \mathrm{E}-08$ & $1.08 \mathrm{E}-05$ & $1.65 \mathrm{E}-08$ & $6.51 \mathrm{E}-06$ & $1.73 \mathrm{E}-05$ \\
\hline Si-32 & $1.68 \mathrm{E}-10$ & 4.39E-08 & $6.72 \mathrm{E}-11$ & $2.65 \mathrm{E}-08$ & 7.04E-08 \\
\hline P-32 & $1.68 \mathrm{E}-10$ & $4.39 \mathrm{E}-08$ & $6.72 \mathrm{E}-11$ & $2.65 \mathrm{E}-08$ & $7.04 \mathrm{E}-08$ \\
\hline Fe-55 & $5.29 \mathrm{E}-01$ & $1.38 \mathrm{E}+02$ & $5.29 E-01$ & $2.09 \mathrm{E}+02$ & $3.47 E+02$ \\
\hline Fe-60 & 1.64E-09 & 4.29E-07 & $6.56 \mathrm{E}-10$ & $2.59 \mathrm{E}-07$ & $6.88 \mathrm{E}-07$ \\
\hline Co-60 & $1.21 \mathrm{E}-02$ & $3.15 \mathrm{E}+00$ & $1.15 \mathrm{E}-02$ & $4.54 \mathrm{E}+00$ & $7.69 \mathrm{E}+00$ \\
\hline Co-60m & 1.64E-09 & $4.29 E-07$ & $6.56 \mathrm{E}-10$ & $2.59 \mathrm{E}-07$ & $6.88 \mathrm{E}-07$ \\
\hline $\mathrm{Ni}-59$ & $1.65 \mathrm{E}-03$ & $4.31 \mathrm{E}-01$ & $1.65 \mathrm{E}-03$ & $6.51 \mathrm{E}-01$ & $1.08 \mathrm{E}+00$ \\
\hline $\mathrm{Ni}-63$ & $4.58 \mathrm{E}-01$ & $1.20 \mathrm{E}+02$ & $4.58 \mathrm{E}-01$ & $1.81 E+02$ & $3.00 E+02$ \\
\hline$Z n-65$ & $1.15 \mathrm{E}-10$ & $3.00 \mathrm{E}-08$ & $4.58 \mathrm{E}-11$ & $1.81 \mathrm{E}-08$ & $4.81 \mathrm{E}-08$ \\
\hline Total & & $2.61 \mathrm{E}+02$ & & $3.95 E+02$ & $6.6 \mathrm{E}+02$ \\
\hline
\end{tabular}

\subsection{EFFECT OF IRRADIATION TIME, NEUTRON FLUX AND DECAY ON NUCLIDE FRACTION AND ESTIMATED ACTIVITY}

\subsubsection{Irradiation Time and Decay}

The activation process resulting in the production of the radionuclides in the mixture is dependent on the amount (mass) of each element present, the target element's neutron cross section, neutron flux, half-life of the activation product, time exposed to the flux and decay time after irradiation (Equation 4). 


\section{Equation 4: Neutron Activation Equation}

Where:

$$
\mathbf{A}=\mathbf{N}\left(\sigma_{\text {th }} \phi_{\text {th }}+I_{0} \phi_{\text {res }}\right)\left(1-\mathbf{e}^{-\lambda \tau_{\text {irr }}}\right)\left(\mathbf{e}^{-\lambda t_{w}}\right)
$$

$$
\begin{aligned}
& \mathrm{A}=\text { activity } \\
& \mathrm{N}=\text { number of atoms of target element } \\
& \sigma_{\mathrm{th}}=\text { thermal neutron cross section } \\
& \phi_{\mathrm{th}}=\text { thermal neutron flux } \\
& \mathrm{I}_{0}=\text { resonance integral } \\
& \phi_{\mathrm{res}}=\text { epithermal flux } \\
& \lambda=\text { decay constant } \\
& \mathrm{t}_{\mathrm{irr}}=\text { irradiation time } \\
& \mathrm{t}_{\mathrm{w}}=\text { decay time }
\end{aligned}
$$

\begin{tabular}{|c|c|c|c|c|}
\hline Irradiation / Decay Period & 1 & 2 & 3 & 4 \\
\hline Irradiation Period (years) & $7.62 \mathrm{E}+00$ & $7.40 \mathrm{E}+00$ & $2.50 E+00$ & $6.08 \mathrm{E}+00$ \\
\hline Decay Period (years) & $6.30 \mathrm{E}-02$ & $2.48 \mathrm{E}-01$ & $3.51 \mathrm{E}+00$ & $2.04 \mathrm{E}+01$ \\
\hline $\mathrm{H}-3$ & 4.26E-05 & $4.28 \mathrm{E}-05$ & 4.36E-05 & $4.34 \mathrm{E}-05$ \\
\hline Al-26 & $9.74 \mathrm{E}-09$ & 9.83E-09 & $1.01 \mathrm{E}-08$ & $1.21 \mathrm{E}-08$ \\
\hline C-14 & $3.33 \mathrm{E}-08$ & $3.35 \mathrm{E}-08$ & $3.44 \mathrm{E}-08$ & 4.13E-08 \\
\hline Si-32 & $1.39 \mathrm{E}-10$ & $1.40 \mathrm{E}-10$ & $1.43 \mathrm{E}-10$ & $1.68 \mathrm{E}-10$ \\
\hline P-32 & $1.39 \mathrm{E}-10$ & $1.40 \mathrm{E}-10$ & $1.43 \mathrm{E}-10$ & $1.68 \mathrm{E}-10$ \\
\hline Fe-55 & $6.05 \mathrm{E}-01$ & $6.01 \mathrm{E}-01$ & $5.92 \mathrm{E}-01$ & $5.29 E-01$ \\
\hline Fe-60 & $1.32 \mathrm{E}-09$ & $1.33 \mathrm{E}-09$ & 1.37E-09 & $1.64 \mathrm{E}-09$ \\
\hline Co-60 & $1.31 \mathrm{E}-02$ & $1.31 \mathrm{E}-02$ & $1.32 \mathrm{E}-02$ & $1.21 \mathrm{E}-02$ \\
\hline Co-60m & $1.32 \mathrm{E}-09$ & $1.33 \mathrm{E}-09$ & 1.37E-09 & $1.64 \mathrm{E}-09$ \\
\hline $\mathrm{Ni}-59$ & $1.33 \mathrm{E}-03$ & $1.34 \mathrm{E}-03$ & $1.37 \mathrm{E}-03$ & $1.65 \mathrm{E}-03$ \\
\hline $\mathrm{Ni}-63$ & $3.81 \mathrm{E}-01$ & $3.84 \mathrm{E}-01$ & $3.94 \mathrm{E}-01$ & $4.58 \mathrm{E}-01$ \\
\hline Zn-65 & $1.54 \mathrm{E}-10$ & $1.44 \mathrm{E}-10$ & $1.29 \mathrm{E}-10$ & $1.15 \mathrm{E}-10$ \\
\hline Total Activity for $3.154 \mathrm{Ci}$ Co-60 & $2.41 E+02$ & $2.41 E+02$ & $2.39 \mathrm{E}+02$ & $2.61 \mathrm{E}+02$ \\
\hline
\end{tabular}

The characterization methodology for the beryllium cage used for developing the source term distribution had four irradiation and decay periods from 1966 to 2021 (Navarro, et al. 2021). Using these results and Equation 4, the isotopic distribution after each irradiation and decay period were calculated to determine how the storage can distribution changes for each irradiation and decay period (Table 17).

Table 15: Nuclide Fraction After Irradiation and Decay Periods

As can be seen in Table 15, the calculated activity determined from $3.154 \mathrm{Ci}$ of Co-60 is the highest after the fourth irradiation and decay period which was used to estimate the activity in 5.1.6. This shows conservatism in using the isotopic distributions from the previously performed modeling.

\subsubsection{Neutron Flux}

Some of the material in the pool were in different reactor locations than the cage. This results in a different proportion of thermal, epithermal, and fast neutron fluxes and could impact the radionuclide distribution from activation as shown in Equation 4. As was stated earlier, the 
model used to determine the nuclide activity distribution was based on material at the maximum flux location at the reflector cage position in the reactor. This position has a high thermal neutron flux. To determine the effect of different neutron flux energies, additional modeling was conducted for placement of aluminum and stainless steel at the center of the flux trap which has the worst case fast and epithermal neutron flux. This allows for comparison of the isotopic distributions as it pertains to the location in the reactor. Table 16 and Table 17 show the isotopic distributions for aluminum and 304 stainless steel placed in the reactor flux trap.

Table 16. (100\%) Aluminum Isotopic Distribution for Flux Trap Location (Mar-2021)

\begin{tabular}{|c|c|c|}
\hline $\begin{array}{c}\text { Aluminum } \\
\text { Isotopic } \\
\text { Distribution }\end{array}$ & $\begin{array}{c}\text { Ci/cm } \\
\text { H-3 }\end{array}$ & $\begin{array}{c}\text { Activity } \\
\text { Fraction }\end{array}$ \\
\hline C-14 & $7.15 \mathrm{E}-03$ & $3.19 \mathrm{E}-02$ \\
\hline Al-26 & $2.75 \mathrm{E}-09$ & $7.16 \mathrm{E}-08$ \\
\hline Si-32 & $4.56 \mathrm{E}-08$ & $2.78 \mathrm{E}-05$ \\
\hline P-32 & $4.56 \mathrm{E}-08$ & $4.61 \mathrm{E}-07$ \\
\hline Fe-55 & $8.91 \mathrm{E}-05$ & $9.61 \mathrm{E}-07$ \\
\hline Fe-60 & $1.61 \mathrm{E}-06$ & $1.63 \mathrm{E}-05$ \\
\hline Co-60 & $8.98 \mathrm{E}-02$ & $9.09 \mathrm{E}-01$ \\
\hline Co-60m & $1.61 \mathrm{E}-06$ & $1.63 \mathrm{E}-05$ \\
\hline Ni-63 & $5.78 \mathrm{E}-03$ & $5.85 \mathrm{E}-02$ \\
\hline Se-79 & $3.80 \mathrm{E}-09$ & $3.84 \mathrm{E}-08$ \\
\hline Kr-85 & $1.93 \mathrm{E}-08$ & $1.95 \mathrm{E}-07$ \\
\hline Total & $\mathbf{9 . 8 9 E}-02$ & \\
\hline
\end{tabular}

Table 17. (100\%) Stainless Steel Isotopic Distribution for Flux Trap Location (Mar-2021)

\begin{tabular}{|c|c|c|}
$\begin{array}{c}\text { 304 Stainless } \\
\text { Steel Isotopic } \\
\text { Distribution }\end{array}$ & $\begin{array}{c}\text { Ci/cm } \\
\text { H-3 }\end{array}$ & $\begin{array}{c}\text { Activity } \\
\text { Fraction }\end{array}$ \\
\hline C-14 & $2.99 \mathrm{E}-03$ & $1.42 \mathrm{E}-04$ \\
\hline Si-32 & $6.22 \mathrm{E}-07$ & $2.96 \mathrm{E}-08$ \\
\hline P-32 & $6.17 \mathrm{E}-07$ & $2.94 \mathrm{E}-08$ \\
\hline Mn-54 & $3.88 \mathrm{E}-07$ & $2.94 \mathrm{E}-08$ \\
\hline Fe-55 & $1.07 \mathrm{E}+00$ & $1.85 \mathrm{E}-08$ \\
\hline Fe-60 & $2.18 \mathrm{E}-04$ & $5.08 \mathrm{E}-02$ \\
\hline Co-60 & $1.84 \mathrm{E}+01$ & $1.04 \mathrm{E}-05$ \\
\hline Co-60m & $2.18 \mathrm{E}-04$ & $8.74 \mathrm{E}-01$ \\
\hline Ni-59 & $2.12 \mathrm{E}-05$ & $1.04 \mathrm{E}-05$ \\
\hline Ni-63 & $1.58 \mathrm{E}+00$ & $1.01 \mathrm{E}-06$ \\
\hline Total & $\mathbf{2 . 1 0 E}+\mathbf{0 1}$ & \\
\hline
\end{tabular}


As can be seen in Table 16 and Table 17, the Co-60 activity fraction is significantly higher for aluminum alloys (9.09E-01 vs 5.43-01) and stainless steels (8.74E-01 vs $1.11 \mathrm{E}-02)$ activated in the flux trap than at the reflector cage location (Table 2 and Table 3 ). Since total activity is inversely proportional to the Co-60 activity fraction, using the isotopic distributions from the reflector cage location is conservative since it would result in a higher total activity.

Equation 4 also shows that the activity is directly proportional to neutron flux. However, since the cross sections are constant and specific to the material, the relative ratios of the activities will also remain constant. Therefore, it is appropriate to use the relative activity ratios in the dose-tocurie method to determine the total and isotopic activities for items that may have been in a different reactor location and having a different (i.e., lower) neutron flux.

\section{CONCLUSIONS AND RECOMMENDATIONS}

An approach to determine conservative radionuclide activity using expected neutron activation products, current volumetric fractions, and field radiological measurements was developed and applied. Based on the field measurements and computer modeling of the storage can, the total radionuclide activity content of all pool waste for disposal is estimated to be $660 \mathrm{Ci}$. The methodology presented in this report was based on using different sources of experimental and simulation methods to obtain a better state of the system. The author also determined a conservative isotopic inventory corresponding to the metal volumetric fractions for both categories of waste (Table 14). In conclusion these activities can be used for shipping and disposal of this waste. 


\section{REFERENCES}

15 U.S.C. $\S 206$. n.d. Standard Gauge for Sheet and Plate Iron and Steel.

Ellis, Mark. June 16, 2020. Radiation / Contamination Job Coverage Survey for Operations Flashing Beryllium Cage, HFIR-537801.

Grove Software, Inc. 1992. MicroShield User's Manual.

Navarro, Jorge, Scott A. Byers, Randal E. Pudelek, Geoffrey G. Deichert, Young Soo Kwon, Russ Wools, Mathew A. Grooms, and David G Blanchard. 2021. Development of an Activation Analysis Methodology to Support the Disposal of the High Flux Isotope Reactor Original Reflector Container.

Union Carbide Nuclear Company, Oak Ridge National Laboratory. November 15, 1983. Engineering Facility Tubes Misc. Details.

UT-Battelle, Oak Ridge National Laboratory. January 4, 2018. Large Pool Storage Can, M10070-0A-344, Rev 1. 


\section{APPENDICES}

\subsection{APPENDIX A - STORAGE CAN INVENTORY}

\begin{tabular}{|c|c|c|c|c|c|c|}
\hline Item Description & $\begin{array}{l}\text { Weight } \\
\text { (lbs) }\end{array}$ & $\begin{array}{l}\text { Material } \\
\text { Group }\end{array}$ & Material & $\ln$ & $\begin{array}{l}\text { Max } \\
\text { Exp. } \\
\text { Rate } \\
(\mathrm{mR} / \mathrm{h})\end{array}$ & Vessel location \\
\hline $\begin{array}{l}\text { Snap ring screwdriver (notches } \\
\text { on side of blade) }\end{array}$ & 0.25 & SS & Carbon Steel & $\mathrm{N}$ & 100 & never in core \\
\hline Ratchet adapter $3 / 8^{\prime \prime}$ to $1 / 2^{\prime \prime}$ & 0.1 & SS & Carbon Steel & $\mathrm{N}$ & 100 & never in core \\
\hline Broken piece with stud & 0.25 & SS & SS & $\mathrm{N}$ & 100 & never in core \\
\hline Hole Saw & 2 & SS & Carbon Steel & $\mathrm{N}$ & 11,000 & never in core \\
\hline Hole Saw & 2 & SS & Carbon Steel & $\mathrm{N}$ & 100 & never in core \\
\hline Hole Saw & 2 & SS & Carbon Steel & $\mathrm{N}$ & 100 & never in core \\
\hline Hole Saw & 2 & SS & Carbon Steel & $\mathrm{N}$ & 7,000 & never in core \\
\hline Hole Saw & 2 & SS & Carbon Steel & $\mathrm{N}$ & 15,000 & never in core \\
\hline Hole Saw & 2 & SS & Carbon Steel & $\mathrm{N}$ & 11,000 & never in core \\
\hline tool hanging chain & 0.25 & SS & Carbon Steel & $\mathrm{N}$ & 100 & never in core \\
\hline Hook tool & 0.25 & SS & 300 series SS & $\mathrm{N}$ & 100 & never in core \\
\hline Hook tool & 0.25 & SS & 300 series SS & $\mathrm{N}$ & 100 & never in core \\
\hline Hook tool & 0.25 & SS & 300 series SS & $\mathrm{N}$ & 100 & never in core \\
\hline Socket & 0.1 & SS & Carbon Steel & $\mathrm{N}$ & 100 & never in core \\
\hline Screwdriver handle & 0.1 & SS & Carbon Steel & $\mathrm{N}$ & 100 & never in core \\
\hline Hole Saw & 0.2 & SS & Carbon Steel & $\mathrm{N}$ & 8,000 & never in core \\
\hline Control Plate (truncated) $10-3$ & 7 & Al & Al 6061-T6 & $\mathrm{Y}$ & 16,000 & $\begin{array}{l}\text { slightly below midplane just outside } \\
\text { of fuel }\end{array}$ \\
\hline Exp. In Inpile & 2 & Al & Al 6061-T6 & Y & 28,000 & midplane in core \\
\hline Exp. In Inpile & 2 & Al & Al 6061-T6 & Y & 500 & midplane in core \\
\hline $\begin{array}{l}\text { Vessel Specimen holder Key } \\
\text { Rack }\end{array}$ & 7 & SS & 304 SS & $\mathrm{Y}$ & 2,000 & $\begin{array}{l}\text { inside vessel on outer wall } \\
\text { midplane }\end{array}$ \\
\hline EF Water Guide Sleeve & 10 & Al & Al 6061-T6 & Y & 1,000 & outside perm beryllium and below \\
\hline $\begin{array}{l}\text { EF Tube Cooling Water Guide } \\
\text { Sleeve segment }\end{array}$ & 5 & $\mathrm{Al}$ & Al 6061-T6 & $\mathrm{Y}$ & 4,000 & outside perm beryllium \\
\hline $\begin{array}{l}\text { EF Cooling Tube Water Guide } \\
\text { Sleeve with NAPA Hose }\end{array}$ & 7 & Al & Al 6061-T6 & $\mathrm{Y}$ & 500 & outside perm beryllium and below \\
\hline RB Liner Tube Assembly & 5 & Al & Al 6061-T6 & Y & 2,000 & in rb midplane \\
\hline Bracket pulled out from Item 21 & 1 & Al & Al & Y & 1,000 & not in vessel \\
\hline $\begin{array}{l}\text { VH-12 to VXF-18 guide Tube } \\
\text { with reducer on end, cut open } \\
\text { on side }\end{array}$ & 12 & SS & 304 SS & $Y$ & 1,500 & above perm beryllium \\
\hline $\begin{array}{l}\text { VH-1 to VXF- } 5 \text { guide Tube with } \\
\text { reducer on end, cut open on } \\
\text { side (band of rust) }\end{array}$ & 12 & SS & 304 SS & Y & 2,000 & above perm beryllium \\
\hline Crap plug sample rod & 1 & Al & Al 6061-T6 & Y & 4,000 & in crap midplane \\
\hline Target Bundle Rod (88-20) & 1 & Al & Al 6061-T6 & $Y$ & 4,000 & in center of target bundle \\
\hline $\begin{array}{l}\text { CRAP holddown bolt, nut \& } \\
\text { washer }\end{array}$ & 1 & Al & Al 6061-T6 & $\mathrm{Y}$ & 30,000 & in middle of crap midplane \\
\hline Dummy Exp & 2 & Al & Al 6061-T6 & $Y$ & 3,000 & in rb midplane \\
\hline Inpile (cutoff section end) & 2 & $\mathrm{Al}$ & Al 6061-T6 & $\mathrm{Y}$ & 3,500 & midplane in core \\
\hline
\end{tabular}




\begin{tabular}{|c|c|c|c|c|c|c|}
\hline RB Baffle Plate & 1 & Al & Al 6061-T6 & Y & 8,500 & top edge of $r b$ \\
\hline Dummy Target Element & 1 & $\mathrm{Al}$ & Al 6061-T6 & Y & 11,000 & in center of target bundle \\
\hline VXF Liner with Lead Tube. & 4 & SS & 300 series SS & Y & 6,000 & in permanent beryllium midplane \\
\hline VXF Liner with Lead Tube (78-1) & 4 & SS & 300 series SS & $\mathrm{Y}$ & 300 & in permanent beryllium midplane \\
\hline VXF Liner with Lead Tube (78-2) & 4 & SS & 300 series SS & Y & 200 & in permanent beryllium midplane \\
\hline RB thru bolt and nut & 1 & $\mathrm{Al}$ & Al 6061-T6 & $\mathrm{Y}$ & 2,000 & in rb midplane \\
\hline Inpile end section & 1 & $\mathrm{Al}$ & Al 6061-T6 & Y & 400 & midplane in core \\
\hline RB thru bolt and nut & 1 & $\mathrm{Al}$ & Al 6061-T6 & $\mathrm{Y}$ & 1,800 & in rb midplane \\
\hline Bottom of VXF Liner & 1 & SS & 300 series SS & Y & 100 & in permanent beryllium midplane \\
\hline RB Liner tube & 1 & $\mathrm{Al}$ & Al 6061-T6 & $\mathrm{Y}$ & 600 & in rb midplane \\
\hline VXF Liner top broke off & 1 & SS & 304 SS & Y & 100 & in permanent beryllium midplane \\
\hline $\begin{array}{l}\text { XE production Facility target 76- } \\
2\end{array}$ & 1 & $\mathrm{Al}$ & Al 6061-T6 & $\mathrm{Y}$ & 100 & midplane in core \\
\hline $\begin{array}{l}\text { XE production Facility target 76- } \\
1\end{array}$ & 1 & $\mathrm{Al}$ & Al 6061-T6 & Y & 500 & midplane in core \\
\hline Cutoff target rod, $\mathrm{H}-27$ & 0.5 & $\mathrm{Al}$ & Al 6061-T6 & Y & 200 & in center of target bundle \\
\hline RB thru bolt and nut & 1 & Al & Al 6061-T6 & Y & 4,600 & in rb midplane \\
\hline CRAP Hanger & 0.5 & $\mathrm{Al}$ & Al 6061-T6 & Y & 7,400 & midplane in core \\
\hline CRAP Hanger & 0.5 & $\mathrm{Al}$ & Al 6061-T6 & Y & 7,200 & midplane in core \\
\hline CRAP Hanger & 0.5 & $\mathrm{Al}$ & Al 6061-T6 & Y & 3,500 & midplane in core \\
\hline CRAP Hanger & 0.5 & $\mathrm{Al}$ & Al 6061-T6 & Y & 6,100 & midplane in core \\
\hline RB thru bolt and nut & 1 & $\mathrm{Al}$ & Al 6061-T6 & $\mathrm{Y}$ & 2,100 & in rb midplane \\
\hline RB thru bolt and nut & 1 & $\mathrm{Al}$ & Al 6061-T6 & $Y$ & 2,500 & in rb midplane \\
\hline RB thru bolt and nut & 1 & $\mathrm{Al}$ & Al 6061-T6 & $\mathrm{Y}$ & 2,500 & in rb midplane \\
\hline RB thru bolt and nut & 1 & $\mathrm{Al}$ & Al 6061-T6 & Y & 2,500 & in rb midplane \\
\hline Inpile end cutoff & 0.25 & $\mathrm{Al}$ & Al 6061-T6 & Y & 2,000 & in center of target bundle \\
\hline RB thru bolt and nut & 1 & $\mathrm{Al}$ & Al 6061-T6 & $\mathrm{Y}$ & 2,600 & in rb midplane \\
\hline Broken shrouded target rod & 1 & $\mathrm{Al}$ & Al 6061-T6 & Y & 17,000 & in center of target bundle \\
\hline VXF exp liner- VH to VXF & 2.5 & SS & 304 SS & Y & 5,000 & above perm beryllium \\
\hline $\begin{array}{l}\text { Pneumatic tube section (old PT- } \\
\text { 1) }\end{array}$ & 10 & SS & 304 SS & Y & 25,000 & above perm beryllium \\
\hline RB flow baffle & 0.25 & $\mathrm{Al}$ & Al 6061-T6 & Y & 300 & top edge of $r b$ \\
\hline RB flow baffle & 0.25 & $\mathrm{Al}$ & Al 6061-T6 & Y & 300 & top edge of rb \\
\hline RB flow baffle & 0.25 & $\mathrm{Al}$ & Al 6061-T6 & Y & 300 & top edge of $r b$ \\
\hline RB flow baffle & 0.25 & $\mathrm{Al}$ & Al 6061-T6 & $Y$ & 600 & top edge of $r b$ \\
\hline RB flow baffle & 0.25 & $\mathrm{Al}$ & Al 6061-T6 & $Y$ & 300 & top edge of $r b$ \\
\hline RB flow baffle & 0.25 & $\mathrm{Al}$ & Al 6061-T6 & $\mathrm{Y}$ & 200 & top edge of rb \\
\hline RB flow baffle & 0.25 & $\mathrm{Al}$ & Al 6061-T6 & Y & 500 & top edge of $r b$ \\
\hline RB flow baffle & 0.25 & $\mathrm{Al}$ & Al 6061-T6 & $Y$ & 400 & top edge of $r b$ \\
\hline $\begin{array}{l}\text { Removable Reflector upper } \\
\text { baffle ring segment }\end{array}$ & 0.25 & $\mathrm{Al}$ & Al 6061-T6 & Y & 16,000 & top edge of $r b$ \\
\hline $\begin{array}{l}\text { Removable Reflector lower } \\
\text { baffle ring segment }\end{array}$ & 0.25 & $\mathrm{Al}$ & Al 6061-T6 & $\mathrm{Y}$ & 300 & top edge of $r b$ \\
\hline
\end{tabular}




\begin{tabular}{|c|c|c|c|c|c|c|}
\hline $\begin{array}{l}\text { Removable Reflector upper } \\
\text { baffle ring segment }\end{array}$ & 0.25 & $\mathrm{Al}$ & Al 6061-T6 & $\mathrm{Y}$ & 28,000 & top edge of $r b$ \\
\hline $\begin{array}{l}\text { Inpile mid section broke off of } \\
\text { item } 92\end{array}$ & 2 & $\mathrm{Al}$ & Al 6061-T6 & $\mathrm{Y}$ & 7,000 & in center of target bundle \\
\hline Dummy rabbit & 0.1 & $\mathrm{Al}$ & Al 6061-T6 & $\mathrm{Y}$ & 3,200 & midplane in core \\
\hline $\begin{array}{l}\text { Control Plate coupling special } \\
\text { washer( } 2 \text { washers in barrel) }\end{array}$ & 0.1 & SS & $17-4$ ph SS & $\mathrm{Y}$ & 300 & bottom of control plate \\
\hline $\begin{array}{l}\text { Bearing press tool yoke for plate } \\
\text { work }\end{array}$ & 0.25 & SS & 300 series SS & $\mathrm{Y}$ & 2,000 & used in mandrel box never in core \\
\hline $\begin{array}{l}\text { Control Plate coupling Bellville } \\
\text { spring( } 2 \text { springs in barrel) }\end{array}$ & 0.1 & SS & $17-4$ ph SS & $\mathrm{Y}$ & 100 & bottom of control plate \\
\hline Beam tube end & 2 & SS & 304 SS & $\mathrm{Y}$ & 300 & midplane in core \\
\hline CRAP lifting eye & 0.2 & $\mathrm{Al}$ & Al 6061-T6 & $\mathrm{Y}$ & 1,200 & top edge of rb \\
\hline CRAP lifting eye & 0.2 & $\mathrm{Al}$ & Al 6061-T6 & $\mathrm{Y}$ & 800 & top edge of $r b$ \\
\hline Reflector Cage cutoff segment & 1 & $\mathrm{Al}$ & Al 6061-T6 & $\mathrm{Y}$ & 500 & top edge of cage \\
\hline $\begin{array}{l}\text { Control Plate coupling retainer } \\
\text { washer (only } 1 \text { ) }\end{array}$ & 0.1 & SS & $17-4$ ph SS & $\mathrm{Y}$ & 600 & bottom of control plate \\
\hline $\begin{array}{l}\text { Control Plate coupling Snap ring } \\
\text { ( } 8 \text { rings in barrel) }\end{array}$ & 0.25 & SS & 302 SS & $\mathrm{Y}$ & 100 & bottom of control plate \\
\hline Track Bearing Shaft & 0.1 & SS & 304 SS & $\mathrm{Y}$ & 2,900 & above or below midplane \\
\hline $\begin{array}{l}\text { Removable Reflector upper } \\
\text { baffle ring segment }\end{array}$ & 0.2 & $\mathrm{Al}$ & Al 6061-T6 & $\mathrm{Y}$ & 29,000 & top edge of rb \\
\hline CRAP lifting eye & 0.2 & $\mathrm{Al}$ & Al 6061-T6 & $\mathrm{Y}$ & 2,100 & top edge of rb \\
\hline Dummy rabbit & 0.1 & $\mathrm{Al}$ & Al 6061-T6 & $\mathrm{Y}$ & 6,300 & in center of target bundle \\
\hline Piece of Dummy Rabbit & 0.1 & $\mathrm{Al}$ & Al 6061-T6 & $\mathrm{Y}$ & 4,500 & in center of target bundle \\
\hline $\begin{array}{l}\text { Removable Reflector lower } \\
\text { baffle ring segment }\end{array}$ & 0.1 & $\mathrm{Al}$ & Al 6061-T6 & $\mathrm{Y}$ & 10,000 & top edge of rb \\
\hline tubing & 1 & SS & SS & $\mathrm{Y}$ & 1,200 & side of cage \\
\hline Collector Cooling Piping & 5 & SS & 304 SS & $\mathrm{Y}$ & 7,500 & $\begin{array}{l}\text { above beam tube outside of } \\
\text { permanent be }\end{array}$ \\
\hline Target Bundle Rod dummy & 1 & $\mathrm{Al}$ & Al 6061-T6 & $Y$ & 22,000 & in center of target bundle \\
\hline Target Bundle Rod dummy & 1 & $\mathrm{Al}$ & Al 6061-T6 & $\mathrm{Y}$ & 8,900 & in center of target bundle \\
\hline PTP Rod & 1 & $\mathrm{Al}$ & Al 6061-T6 & $\mathrm{Y}$ & 4,500 & in target bundle \\
\hline tubing & 0.5 & SS & SS & $\mathrm{Y}$ & 800 & side of cage \\
\hline Broken shrouded target rod & 1 & $\mathrm{Al}$ & Al 6061-T6 & $Y$ & 32,000 & in center of target bundle \\
\hline RB thru bolt and nut & 1 & $\mathrm{Al}$ & Al 6061-T6 & $\mathrm{Y}$ & 4,500 & in rb midplane \\
\hline VXF liner & 1 & $\mathrm{Al}$ & Al 6061-T6 & $Y$ & 12,700 & in permanent beryllium midplane \\
\hline Broken PTP rod & 0.5 & Al & Al 6061-T6 & $\mathrm{Y}$ & 30,000 & in target bundle \\
\hline Broken PTP rod & 0.5 & $\mathrm{Al}$ & Al 6061-T6 & $\mathrm{Y}$ & 24,000 & in target bundle \\
\hline PT-1 Supply-Exhaust tube & 0.5 & SS & 304 SS & $\mathrm{Y}$ & 2,400 & above perm beryllium \\
\hline PT-1 Supply-Exhaust tube & 0.5 & SS & 304 SS & $\mathrm{Y}$ & 600 & above perm beryllium \\
\hline Top Adapter PT-1 & 1 & SS & 304 SS & $\mathrm{Y}$ & 2,200 & above perm beryllium \\
\hline
\end{tabular}




\begin{tabular}{|c|c|c|c|c|c|c|}
\hline RB thru bolt and nut & 1 & $\mathrm{Al}$ & Al 6061-T6 & $Y$ & 3,500 & in rb midplane \\
\hline PT-1 Supply-Exhaust tube & 0.5 & SS & 304 SS & $\mathrm{Y}$ & 1,000 & above perm beryllium \\
\hline Pintle head slotted rod & 0.5 & SS & 304 SS & $\mathrm{Y}$ & 15,000 & midplane in core \\
\hline PT-1 Supply-Exhaust tube & 0.5 & SS & 304 SS & $\mathrm{Y}$ & 1,300 & above perm beryllium \\
\hline PT-1 Supply-Exhaust tube & 0.5 & SS & 304 SS & $\mathrm{Y}$ & 400 & above perm beryllium \\
\hline PT-1 Supply-Exhaust tube & 0.5 & SS & 304 SS & $Y$ & 2,800 & above perm beryllium \\
\hline PT-1 Supply-Exhaust tube & 0.5 & SS & 304 SS & $Y$ & 2,200 & above perm beryllium \\
\hline RB thru bolt and nut & 1 & $\mathrm{Al}$ & Al 6061-T6 & $\mathrm{Y}$ & 2,400 & in rb midplane \\
\hline CRAP Hanger & 0.5 & $\mathrm{Al}$ & Al 6061-T6 & $Y$ & 5,300 & top edge of $r b$ \\
\hline RB flow baffle (qty 3) & 1.5 & $\mathrm{Al}$ & Al 6061-T6 & $Y$ & 600 & top edge of $r b$ \\
\hline RB inner cylinder spacer strip & 1 & $\mathrm{Al}$ & Al 6061-T6 & $\mathrm{Y}$ & 3,500 & in rb midplane \\
\hline RB thru bolt and nut & 15 & $\mathrm{Al}$ & Al 6061-T6 & $Y$ & 13,800 & in rb midplane \\
\hline RB Baffle Plate lower segment & 1 & $\mathrm{Al}$ & Al 6061-T6 & $\mathrm{Y}$ & 1,000 & top edge of rb \\
\hline item cutoff of cage & 5 & $\mathrm{Al}$ & Al 6061-T6 & $Y$ & 38,500 & cage bottom of rb area \\
\hline item cutoff of cage & 5 & $\mathrm{Al}$ & Al 6061-T6 & $\mathrm{Y}$ & 20,000 & cage bottom of rb area \\
\hline item cutoff of cage & 5 & $\mathrm{Al}$ & Al 6061-T6 & $\mathrm{Y}$ & 29,500 & cage bottom of rb area \\
\hline item cutoff of cage & 5 & $\mathrm{Al}$ & Al 6061-T6 & $\mathrm{Y}$ & 20,000 & cage bottom of rb area \\
\hline $\begin{array}{l}\text { Pressure vessel specimen cover } \\
\text { retainer }\end{array}$ & 10 & SS & 304 SS & $\mathrm{Y}$ & 900 & $\begin{array}{l}\text { around beam tube outside } \\
\text { permanent be }\end{array}$ \\
\hline RB flow baffle pc 11 (qty 9) & 2.25 & $\mathrm{Al}$ & Al 6061-T6 & $Y$ & 7,500 & top edge of rb \\
\hline $\begin{array}{l}\text { RB thru bolt top head } \\
\text { only(drilled thru bolt) (qty } 11 \text { ) }\end{array}$ & 2.2 & $\mathrm{Al}$ & Al 6061-T6 & $\mathrm{Y}$ & 1,500 & top edge of rb \\
\hline RB lower baffle plate & 1 & $\mathrm{Al}$ & Al 6061-T6 & $Y$ & 2,000 & bottom edge of rb \\
\hline $\begin{array}{l}\text { Extension tube segment ( } 6.5 \\
\text { holes) }\end{array}$ & 5 & SS & 347 SS & $\mathrm{Y}$ & 100 & below permanent be \\
\hline $\begin{array}{l}\text { Extension tube segment ( } 5 \\
\text { holes) }\end{array}$ & 5 & SS & 347 SS & $\mathrm{Y}$ & 200 & below permanent be \\
\hline Inner cyclinder nut & 1 & SS & 303 SS & $Y$ & 1,000 & bottom of control cylinder \\
\hline Inner cyclinder nut & 1 & SS & 303 SS & Y & 100 & bottom of control cylinder \\
\hline RB flow baffle & 0.25 & Al & Al 6061-T6 & $\mathrm{Y}$ & 1,100 & top edge of $\mathrm{rb}$ \\
\hline RB thru bolt top head only & 0.2 & $\mathrm{Al}$ & Al 6061-T6 & $Y$ & 600 & in rb midplane \\
\hline $\begin{array}{l}\text { Broken dummy target rod } \\
\text { holder }\end{array}$ & 0.25 & Al & Al 6061-T6 & $\mathrm{Y}$ & 100 & in center of target bundle \\
\hline item cutoff of cage & 10 & $\mathrm{Al}$ & Al 6061-T6 & $Y$ & 20,500 & cage bottom of rb area \\
\hline key for perm Be to cage & 1 & $\mathrm{Al}$ & Al 6061-T6 & $\mathrm{Y}$ & 2,000 & $\begin{array}{l}\text { outer bottom edge of permanent } \\
\text { be on cage }\end{array}$ \\
\hline Spring retainer (for coupling) & 0.1 & SS & 304 SS & $Y$ & 1,000 & bottom of control plate \\
\hline In Rx Aluminum Weight (Ibs) & 135.85 & & & & & \\
\hline In Rx Steel Weight (Ibs) & 94.0 & & & & & \\
\hline Total In-Rx Weight (Ibs) & 229.85 & & & & & \\
\hline
\end{tabular}




\subsection{APPENDIX B - POOL WASTE INVENTORY}

\begin{tabular}{|c|c|c|c|c|c|c|}
\hline Item Description & $\begin{array}{l}\text { Weight } \\
\text { (lbs) }\end{array}$ & $\begin{array}{l}\text { Material } \\
\text { Group }\end{array}$ & Material & $\begin{array}{l}\text { In } \\
\text { Rx }\end{array}$ & $\begin{array}{l}\text { Max } \\
\text { Exp. } \\
\text { Rate } \\
(\mathrm{mR} / \mathrm{h})\end{array}$ & Vessel location \\
\hline Straight Tubing Section & 1 & Al & Al 6061-T6 & $\mathrm{N}$ & 15 & not in vessel \\
\hline $\begin{array}{l}\text { Straight Tubing Section 1/4" } \\
\text { (bent end) }\end{array}$ & 1 & Al & Al 6061-T6 & $\mathrm{N}$ & 60 & not in vessel \\
\hline $\begin{array}{l}\text { RB Liner Tube Assymbly ( } 4 \\
\text { holes @ top) }\end{array}$ & 5 & Al & Al 6061-T6 & $\mathrm{N}$ & 10 & placed into pool but not in vessel \\
\hline $\begin{array}{l}\text { Rad Trash bag with Misc } \\
\text { waste items (Hook tool, saw } \\
\text { blades,etc) }\end{array}$ & 7 & SS & Carbon Steel & $\mathrm{N}$ & 45 & not in vessel \\
\hline spring - conduit & 0.5 & SS & SS & $\mathrm{N}$ & 35 & not in vessel \\
\hline Clamp Bolt & 0.24 & Al & Al 6061-T6 & $\mathrm{N}$ & 1,000 & Unknown \\
\hline $\begin{array}{l}\text { tool part with } 2 \text { pins and } 1 \\
\text { bolt }\end{array}$ & 1 & Al & Al 6061-T6 & $\mathrm{N}$ & 30 & put in rb but never in core \\
\hline RB Liner Tube & 1 & Al & Al 6061-T6 & $\mathrm{N}$ & 35 & not in vessel \\
\hline spacer & 1 & SS & $17-4$ ph SS & $\mathrm{Y}$ & 10 & tip of cage \\
\hline Al Disc & 1 & SS & SS & $\mathrm{Y}$ & 50 & Unknown \\
\hline RB lower containment ring & 20 & Al & Al 6061-T6 & $\mathrm{Y}$ & 30,000 & bottom of RB \\
\hline RB lower containment ring & 20 & $\mathrm{Al}$ & Al 6061-T6 & $\mathrm{Y}$ & 8,000 & bottom of RB \\
\hline RB upper containment ring & 20 & Al & Al 6061-T6 & Y & 12,000 & top of RB \\
\hline RB upper containment ring & 20 & Al & Al 6061-T6 & $\mathrm{Y}$ & 4,000 & top of RB \\
\hline Inpile end & 1 & $\mathrm{Al}$ & Al 6061-T6 & $\mathrm{Y}$ & 6,000 & above centerline of core \\
\hline Inpile end & 1 & Al & Al 6061-T6 & $\mathrm{Y}$ & 2,000 & above centerline of core \\
\hline $\begin{array}{l}\text { Extension tube (69-3) bottom } \\
\text { end }\end{array}$ & 40 & SS & 347 ss & $\mathrm{Y}$ & 500 & below permanent Be \\
\hline $\begin{array}{l}\text { Extension Tube ( } 8 \text { holes } \\
\text { remaining) }\end{array}$ & 25 & SS & 347 SS & $\mathrm{Y}$ & 700 & below permanent Be \\
\hline $\begin{array}{l}\text { Extension Tube ( } 3 \text { holes } \\
\text { remaining) }\end{array}$ & 25 & SS & 347 SS & $\mathrm{Y}$ & 500 & below permanent Be \\
\hline $\begin{array}{l}\text { Extension tube (1 hole } \\
\text { remaining) }\end{array}$ & 25 & SS & 347 SS & $\mathrm{Y}$ & 200 & below permanent Be \\
\hline $\begin{array}{l}\text { Extension tube ( } 1 \text { hole } \\
\text { remaining) }\end{array}$ & 25 & SS & 347 SS & $\mathrm{Y}$ & 10,000 & below permanent $\mathrm{Be}$ \\
\hline In Rx Aluminum Weight (Ibs) & 82 & & & & & \\
\hline In Rx Steel Weight (Ibs) & 142 & & & & & \\
\hline Total In-Rx Weight (Ibs) & 224 & & & & & \\
\hline
\end{tabular}




\subsection{APPENDIX C - STORAGE CAN MICROSHIELD MODEL}

\begin{tabular}{|c|c|c|c|c|c|c|c|}
\hline \multicolumn{8}{|c|}{$\begin{array}{l}\text { MicroShield 8.03 } \\
\text { ORNL (8.03-0000) }\end{array}$} \\
\hline \multicolumn{3}{|c|}{ Date } & \multicolumn{2}{|c|}{ By } & \multicolumn{3}{|c|}{ Checked } \\
\hline \multicolumn{4}{|c|}{ Filename } & \multicolumn{2}{|c|}{ Run Date } & & Duration \\
\hline \multicolumn{4}{|c|}{ GoCan dose profile 2.msd } & \multicolumn{2}{|c|}{ May 3, 2021} & & 00:00:00 \\
\hline \multicolumn{8}{|c|}{ Project Info } \\
\hline \multicolumn{3}{|c|}{ Case Title } & \multicolumn{4}{|c|}{ Storage Can } & \\
\hline \multicolumn{3}{|c|}{ Description } & \multicolumn{5}{|c|}{ Storage Can matching dose profile 1-Ci Co-60 } \\
\hline \multicolumn{3}{|c|}{ Geometry } & \multicolumn{4}{|c|}{7 - Cylinder Volume - Side Shields } & \\
\hline \multicolumn{7}{|c|}{ Source Dimensions } & \\
\hline & Height & \multicolumn{5}{|c|}{$76.518 \mathrm{~cm}(2 \mathrm{ft} 6.1 \mathrm{in})$} & \\
\hline & Radius & \multicolumn{5}{|c|}{$31.869 \mathrm{~cm}(1 \mathrm{ft} 0.5 \mathrm{in})$} & \\
\hline \multicolumn{7}{|c|}{ Dose Points } & \\
\hline A & \multicolumn{2}{|c|}{$\mathbf{X}$} & \multicolumn{2}{|r|}{$\mathbf{Y}$} & \multicolumn{2}{|c|}{$\mathbf{Z}$} & \\
\hline$\# 1$ & \multicolumn{2}{|c|}{$42.228 \mathrm{~cm}(1 \mathrm{ft} 4.6 \mathrm{in})$} & \multicolumn{2}{|c|}{$137.478 \mathrm{~cm}(4 \mathrm{ft} 6.1 \mathrm{in})$} & \multicolumn{2}{|c|}{$0.0 \mathrm{~cm}(0 \mathrm{in})$} & \\
\hline \#25 & \multicolumn{2}{|c|}{$57.468 \mathrm{~cm}(1 \mathrm{ft} 10.6 \mathrm{in})$} & \multicolumn{2}{|c|}{$82.518 \mathrm{~cm}(2 \mathrm{ft} 8.5 \mathrm{in})$} & \multicolumn{2}{|c|}{$0.0 \mathrm{~cm}(0 \mathrm{in})$} & \multirow[t]{2}{*}{ - } \\
\hline \multicolumn{3}{|c|}{$357.468 \mathrm{~cm}(1 \mathrm{ft} 10.6 \mathrm{in})$} & \multicolumn{2}{|c|}{$38.735 \mathrm{~cm}(1 \mathrm{ft} 3.3 \mathrm{in})$} & \multicolumn{2}{|c|}{$0.0 \mathrm{~cm}(0 \mathrm{in})$} & \\
\hline$\# 45$ & $57.468 \mathrm{~cm}($ & $\mathrm{ft} 10.6 \mathrm{in})$ & 4.0 & $\mathrm{n}(1.6 \mathrm{in})$ & $0.0 \mathrm{~cm}$ & in) & $\bullet$ \\
\hline$\# 5$ & $34.607 \mathrm{~cm}$ & ft 1.6 in) & 38.735 & $\mathrm{n}(1 \mathrm{ft} 3.3 \mathrm{in})$ & $0.0 \mathrm{~cm}$ & in) & \\
\hline & & & Shield & & & & \\
\hline & Shield N & Dimen & ision & Material & Den & & \\
\hline & Source & $2.44 \mathrm{e}+0$ & $5 \mathrm{~cm}^{3}$ & Mixed -> & 0.4 & & Z \\
\hline & & & & Aluminum & 0.25 & & \\
\hline & & & & Iron & 0.17 & & \\
\hline & Transition & & & Air & 0.00 & & \\
\hline & Air Gap & & & Air & 0.00 & & \\
\hline & Wall Clad & .198 & $\mathrm{~cm}$ & Iron & $\varepsilon$ & & \\
\hline & Immersion & & & Air & 0.00 & & \\
\hline
\end{tabular}




\begin{tabular}{|c|c|c|c|c|c|}
\hline \multicolumn{6}{|c|}{ Source Input: Grouping Method - Actual Photon Energies } \\
\hline Nuclide & $\mathbf{C i}$ & $\mathrm{Bq}$ & \multicolumn{2}{|c|}{$\mu \mathrm{Ci} / \mathbf{c m}^{3}$} & $\mathrm{~Bq} / \mathrm{cm}^{3}$ \\
\hline Co-60 & $1.0000 \mathrm{e}+000$ & $3.7000 \mathrm{e}+010$ & \multicolumn{2}{|c|}{$4.0959 \mathrm{e}+000$} & $1.5155 \mathrm{e}+005$ \\
\hline \multicolumn{6}{|c|}{$\begin{array}{l}\text { Buildup: The material reference is Source } \\
\text { Integration Parameters }\end{array}$} \\
\hline \multicolumn{5}{|c|}{ Radial } & 10 \\
\hline \multicolumn{5}{|c|}{ Circumferential } & 10 \\
\hline \multicolumn{5}{|c|}{ Y Direction (axial) } & 20 \\
\hline \multicolumn{6}{|c|}{ Results - Dose Point \# 1 - $(42.2275,137.4775,0) \mathrm{cm}$} \\
\hline $\begin{array}{l}\text { Energy } \\
(\mathrm{MeV})\end{array}$ & $\begin{array}{c}\text { Activity } \\
\text { (Photons/sec) }\end{array}$ & \begin{tabular}{|c|} 
Fluence \\
Rate \\
MeV/cm²/sec \\
No Buildup \\
\end{tabular} & \begin{tabular}{|c|} 
Fluence Rate \\
$\mathrm{MeV} / \mathrm{cm}^{2} / \mathrm{sec}$ \\
With \\
Buildup \\
\end{tabular} & $\begin{array}{c}\text { Exposure } \\
\text { Rate } \\
\text { mR/hr } \\
\text { No Buildup }\end{array}$ & $\begin{array}{c}\text { Exposure } \\
\text { Rate } \\
\text { mR/hr } \\
\text { With Buildup }\end{array}$ \\
\hline 0.6938 & $6.035 \mathrm{e}+06$ & $1.347 \mathrm{e}+01$ & $2.271 \mathrm{e}+01$ & $2.600 \mathrm{e}-02$ & $4.384 \mathrm{e}-02$ \\
\hline 1.1732 & $3.700 \mathrm{e}+10$ & $1.622 \mathrm{e}+05$ & $2.406 \mathrm{e}+05$ & $2.899 \mathrm{e}+02$ & $4.299 \mathrm{e}+02$ \\
\hline 1.3325 & $3.700 \mathrm{e}+10$ & $1.908 \mathrm{e}+05$ & $2.752 \mathrm{e}+05$ & $3.310 \mathrm{e}+02$ & $4.774 \mathrm{e}+02$ \\
\hline Totals & $7.401 e+10$ & $3.530 \mathrm{e}+05$ & $5.158 e+05$ & $6.209 \mathrm{e}+02$ & $9.074 \mathrm{e}+02$ \\
\hline \multicolumn{6}{|c|}{ Results - Dose Point \# 2 - $(57.4675,82.5175,0) \mathrm{cm}$} \\
\hline $\begin{array}{l}\text { Energy } \\
(\mathrm{MeV})\end{array}$ & $\begin{array}{c}\text { Activity } \\
\text { (Photons/sec) }\end{array}$ & \begin{tabular}{|c|} 
Fluence \\
Rate \\
MeV/cm²/sec \\
No Buildup
\end{tabular} & \begin{tabular}{|c|} 
Fluence Rate \\
$\mathrm{MeV} / \mathrm{cm}^{2} / \mathrm{sec}$ \\
With \\
Buildup \\
\end{tabular} & $\begin{array}{c}\text { Exposure } \\
\text { Rate } \\
\text { mR/hr } \\
\text { No Buildup }\end{array}$ & $\begin{array}{c}\text { Exposure } \\
\text { Rate } \\
\text { mR/hr } \\
\text { With Buildup }\end{array}$ \\
\hline 0.6938 & $6.035 \mathrm{e}+06$ & $2.765 \mathrm{e}+01$ & $5.095 \mathrm{e}+01$ & $5.339 \mathrm{e}-02$ & $9.836 \mathrm{e}-02$ \\
\hline 1.1732 & $3.700 \mathrm{e}+10$ & $3.436 \mathrm{e}+05$ & $5.388 \mathrm{e}+05$ & $6.141 \mathrm{e}+02$ & $9.628 \mathrm{e}+02$ \\
\hline 1.3325 & $3.700 \mathrm{e}+10$ & $4.065 \mathrm{e}+05$ & $6.161 \mathrm{e}+05$ & $7.053 \mathrm{e}+02$ & $1.069 \mathrm{e}+03$ \\
\hline Totals & $7.401 \mathrm{e}+10$ & $7.502 \mathrm{e}+05$ & $1.155 e+06$ & $1.319 \mathrm{e}+03$ & $2.032 \mathrm{e}+03$ \\
\hline \multicolumn{6}{|c|}{ Results - Dose Point \# 3 - $(57.4675,38.735,0) \mathrm{cm}$} \\
\hline $\begin{array}{l}\text { Energy } \\
(\mathrm{MeV})\end{array}$ & $\begin{array}{c}\text { Activity } \\
\text { (Photons/sec) }\end{array}$ & \begin{tabular}{|c|} 
Fluence \\
Rate \\
MeV/cm²/sec \\
No Buildup
\end{tabular} & \begin{tabular}{|c|} 
Fluence Rate \\
MeV/cm $/$ sec \\
With \\
Buildup \\
\end{tabular} & $\begin{array}{c}\text { Exposure } \\
\text { Rate } \\
\text { mR/hr } \\
\text { No Buildup }\end{array}$ & $\begin{array}{c}\text { Exposure } \\
\text { Rate } \\
\text { mR/hr } \\
\text { With Buildup }\end{array}$ \\
\hline 0.6938 & $6.035 \mathrm{e}+06$ & $4.469 \mathrm{e}+01$ & $7.806 \mathrm{e}+01$ & $8.628 \mathrm{e}-02$ & $1.507 \mathrm{e}-01$ \\
\hline 1.1732 & $3.700 \mathrm{e}+10$ & $5.454 \mathrm{e}+05$ & $8.182 \mathrm{e}+05$ & $9.747 \mathrm{e}+02$ & $1.462 \mathrm{e}+03$ \\
\hline 1.3325 & $3.700 \mathrm{e}+10$ & $6.425 \mathrm{e}+05$ & $9.338 \mathrm{e}+05$ & $1.115 \mathrm{e}+03$ & $1.620 \mathrm{e}+03$ \\
\hline
\end{tabular}




\begin{tabular}{|c|c|c|c|c|c|}
\hline Totals & $7.401 e+10$ & $1.188 \mathrm{e}+06$ & $1.752 \mathrm{e}+06$ & $2.089 \mathrm{e}+03$ & $3.082 \mathrm{e}+03$ \\
\hline \multicolumn{6}{|c|}{ Results - Dose Point \# 4 - $(57.4675,4,0) \mathrm{cm}$} \\
\hline $\begin{array}{c}\text { Energy } \\
(\mathrm{MeV})\end{array}$ & $\begin{array}{c}\text { Activity } \\
\text { (Photons/sec) }\end{array}$ & \begin{tabular}{|c|} 
Fluence \\
Rate \\
MeV/cm²/sec \\
No Buildup
\end{tabular} & \begin{tabular}{|c|} 
Fluence Rate \\
${\mathrm{MeV} / \mathrm{cm}^{2} / \mathrm{sec}}$ \\
With \\
Buildup \\
\end{tabular} & $\begin{array}{c}\text { Exposure } \\
\text { Rate } \\
\text { mR/hr } \\
\text { No Buildup }\end{array}$ & $\begin{array}{c}\text { Exposure } \\
\text { Rate } \\
\text { mR/hr } \\
\text { With Buildup }\end{array}$ \\
\hline 0.6938 & $6.035 \mathrm{e}+06$ & $3.265 \mathrm{e}+01$ & $5.991 \mathrm{e}+01$ & $6.303 \mathrm{e}-02$ & $1.157 \mathrm{e}-01$ \\
\hline 1.1732 & $3.700 \mathrm{e}+10$ & $4.052 \mathrm{e}+05$ & $6.320 \mathrm{e}+05$ & $7.241 \mathrm{e}+02$ & $1.129 \mathrm{e}+03$ \\
\hline 1.3325 & $3.700 \mathrm{e}+10$ & $4.792 \mathrm{e}+05$ & $7.224 \mathrm{e}+05$ & $8.313 \mathrm{e}+02$ & $1.253 \mathrm{e}+03$ \\
\hline Totals & $7.401 e+10$ & $8.844 e+05$ & $1.354 e+06$ & $1.555 e+03$ & $2.383 e+03$ \\
\hline \multicolumn{6}{|c|}{ Results - Dose Point \# 5 - $(3.46 \mathrm{e}+01,38.735,0) \mathrm{cm}$} \\
\hline $\begin{array}{c}\text { Energy } \\
(\mathrm{MeV})\end{array}$ & $\begin{array}{c}\text { Activity } \\
\text { (Photons/sec) }\end{array}$ & \begin{tabular}{|c|} 
Fluence \\
Rate \\
$\mathrm{MeV} / \mathrm{cm}^{2} / \mathrm{sec}$ \\
No Buildup
\end{tabular} & \begin{tabular}{|c|} 
Fluence Rate \\
$\mathrm{MeV} / \mathrm{cm}^{2} / \mathrm{sec}$ \\
With \\
Buildup \\
\end{tabular} & $\begin{array}{c}\text { Exposure } \\
\text { Rate } \\
\text { mR/hr } \\
\text { No Buildup }\end{array}$ & $\begin{array}{c}\text { Exposure } \\
\text { Rate } \\
\text { mR/hr } \\
\text { With Buildup }\end{array}$ \\
\hline 0.6938 & $6.035 \mathrm{e}+06$ & $1.187 \mathrm{e}+02$ & $2.173 \mathrm{e}+02$ & $2.292 \mathrm{e}-01$ & $4.195 \mathrm{e}-01$ \\
\hline 1.1732 & $3.700 \mathrm{e}+10$ & $1.472 \mathrm{e}+06$ & $2.285 \mathrm{e}+06$ & $2.631 \mathrm{e}+03$ & $4.084 \mathrm{e}+03$ \\
\hline 1.3325 & $3.700 \mathrm{e}+10$ & $1.740 \mathrm{e}+06$ & $2.610 \mathrm{e}+06$ & $3.019 \mathrm{e}+03$ & $4.528 \mathrm{e}+03$ \\
\hline Totals & $7.401 e+10$ & $3.213 \mathrm{e}+06$ & $4.895 e+06$ & $5.651 e+03$ & $8.612 e+03$ \\
\hline
\end{tabular}




\subsection{APPENDIX D - EF TUBE MICROSHIELD MODEL}

\begin{tabular}{|c|c|c|c|c|c|c|}
\hline \multicolumn{7}{|c|}{$\begin{array}{l}\text { MicroShield 8.03 } \\
\text { ORNL (8.03-0000) }\end{array}$} \\
\hline \multicolumn{3}{|c|}{ Date } & \multicolumn{2}{|c|}{ By } & \multicolumn{2}{|c|}{ Checked } \\
\hline \multicolumn{3}{|c|}{ Filename } & \multicolumn{2}{|c|}{ Run Date } & Run Tim & Duration \\
\hline \multicolumn{3}{|c|}{ EF Tube.msd } & \multicolumn{2}{|c|}{ May 3, 2021} & $9: 17: 40$ & 00:00:01 \\
\hline \multicolumn{7}{|c|}{ Project Info } \\
\hline \multicolumn{2}{|r|}{ Case Title } & \multicolumn{5}{|c|}{ EF Tube } \\
\hline \multicolumn{2}{|r|}{ Description } & \multicolumn{5}{|c|}{ Tubing Protruding from Storage Can $1 \mathrm{Ci}$ Co-60 } \\
\hline & Geometry & \multicolumn{5}{|c|}{12 - Annular Cylinder - External Dose Point } \\
\hline \multicolumn{6}{|c|}{ Source Dimensions } & \\
\hline \multicolumn{4}{|c|}{ Height } & \multicolumn{2}{|c|}{$60.96 \mathrm{~cm}(2 \mathrm{ft})$} & \\
\hline \multicolumn{4}{|c|}{ Inner Cyl Radius } & \multicolumn{2}{|c|}{$5.874 \mathrm{~cm}(2.3 \mathrm{in})$} & \\
\hline \multicolumn{4}{|c|}{ Inner Cyl Thickness } & \multicolumn{2}{|c|}{$0.0 \mathrm{~cm}(0 \mathrm{in})$} & \\
\hline \multicolumn{4}{|c|}{ Outer Cyl Thickness } & \multicolumn{2}{|c|}{$0.0 \mathrm{~cm}(0 \mathrm{in})$} & \\
\hline \multicolumn{3}{|c|}{ Source } & & \multicolumn{2}{|c|}{$0.239 \mathrm{~cm}(0.1 \mathrm{in})$} & \\
\hline \multicolumn{6}{|c|}{ Dose Points } & \multirow{3}{*}{ 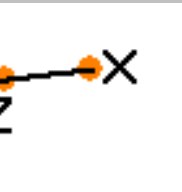 } \\
\hline A & \multicolumn{2}{|l|}{$\mathbf{X}$} & \multicolumn{2}{|c|}{$\mathbf{Y}$} & $\mathbf{Z}$ & \\
\hline$\# 1$ & \multicolumn{2}{|c|}{$16.273 \mathrm{~cm}(6.4 \mathrm{in})$} & 0.0 & ( $(0$ in $)$ & $0.0 \mathrm{~cm}(0 \mathrm{in})$ & \\
\hline \#2. & $49.566 \mathrm{~cm} \mathrm{(1)}$ & $.5 \mathrm{in})$ & 0.0 & ( $(0$ in $)$ & $0.0 \mathrm{~cm}(0 \mathrm{in})$ & 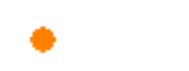 \\
\hline \#3. & $31.513 \mathrm{~cm}(1$ & $.4 \mathrm{in})$ & 60.9 & $\mathrm{~m}(2 \mathrm{ft})$ & $0.0 \mathrm{~cm}(0 \mathrm{in})$ & ․ \\
\hline \#4 & $31.513 \mathrm{~cm}(1$ & $.4 \mathrm{in})$ & $99.219 \mathrm{c}$ & $(3 \mathrm{ft} 3.1 \mathrm{in})$ & $0.0 \mathrm{~cm}(0 \mathrm{in})$ & \\
\hline \#5 3 & $31.513 \mathrm{~cm} \mathrm{(1)}$ & $.4 \mathrm{in})$ & 137.478 & $(4 \mathrm{ft} 6.1 \mathrm{in})$ & $0.0 \mathrm{~cm}(0 \mathrm{in})$ & $\bullet$ \\
\hline & & & Shields & & & \\
\hline & Shield N & Dim & ension & Material & Density & \\
\hline & Cyl. Radius & 5.8 & $74 \mathrm{~cm}$ & Air & 0.00122 & \\
\hline & Source & 548. & $075 \mathrm{~cm}^{3}$ & Iron & 7.86 & \\
\hline & Transition & & & Air & 0.00122 & \\
\hline & Air Gap & & & Air & 0.00122 & \\
\hline & Immersion & & & Air & 0.00122 & \\
\hline
\end{tabular}




\begin{tabular}{|c|c|c|c|c|c|}
\hline \multicolumn{6}{|c|}{ Source Input: Grouping Method - Actual Photon Energies } \\
\hline Nuclide & $\mathbf{C i}$ & $\mathbf{B q}$ & \multicolumn{2}{|c|}{$\mu \mathrm{Ci} / \mathbf{c m}^{3}$} & $\mathrm{~Bq} / \mathrm{cm}^{3}$ \\
\hline Co-60 & $1.0000 \mathrm{e}+000$ & $3.7000 \mathrm{e}+010$ & \multicolumn{2}{|c|}{$1.8246 \mathrm{e}+003$} & $6.7509 \mathrm{e}+007$ \\
\hline \multicolumn{6}{|c|}{$\begin{array}{l}\text { Buildup: The material reference is Source } \\
\text { Integration Parameters }\end{array}$} \\
\hline \multicolumn{5}{|c|}{ Radial } & 10 \\
\hline \multicolumn{5}{|c|}{ Circumferential } & 20 \\
\hline \multicolumn{5}{|c|}{ Y Direction (axial) } & 20 \\
\hline \multicolumn{6}{|c|}{ Results - Dose Point \# 1 - $(16.27251,0,0) \mathrm{cm}$} \\
\hline $\begin{array}{l}\text { Energy } \\
(\mathrm{MeV})\end{array}$ & $\begin{array}{c}\text { Activity } \\
\text { (Photons/sec) }\end{array}$ & \begin{tabular}{|c|} 
Fluence \\
Rate \\
$\mathrm{MeV} / \mathrm{cm}^{2} / \mathbf{s e c}$ \\
No Buildup \\
\end{tabular} & \begin{tabular}{|c|} 
Fluence Rate \\
$\mathrm{MeV} / \mathrm{cm}^{2} / \mathrm{sec}$ \\
With \\
Buildup \\
\end{tabular} & $\begin{array}{c}\text { Exposure } \\
\text { Rate } \\
\text { mR/hr } \\
\text { No Buildup }\end{array}$ & $\begin{array}{c}\text { Exposure } \\
\text { Rate } \\
\text { mR/hr } \\
\text { With Buildup }\end{array}$ \\
\hline 0.6938 & $6.035 \mathrm{e}+06$ & $3.068 \mathrm{e}+02$ & $3.808 \mathrm{e}+02$ & $5.922 \mathrm{e}-01$ & $7.353 \mathrm{e}-01$ \\
\hline 1.1732 & $3.700 \mathrm{e}+10$ & $3.398 \mathrm{e}+06$ & $4.015 \mathrm{e}+06$ & $6.072 \mathrm{e}+03$ & $7.174 \mathrm{e}+03$ \\
\hline 1.3325 & $3.700 \mathrm{e}+10$ & $3.917 \mathrm{e}+06$ & $4.578 \mathrm{e}+06$ & $6.796 \mathrm{e}+03$ & $7.942 \mathrm{e}+03$ \\
\hline Totals & $7.401 e+10$ & $7.315 e+06$ & $8.593 e+06$ & $1.287 \mathrm{e}+04$ & $1.512 \mathrm{e}+04$ \\
\hline \multicolumn{6}{|c|}{ Results - Dose Point \# 2 - $(4.96 \mathrm{e}+01,0,0) \mathrm{cm}$} \\
\hline $\begin{array}{l}\text { Energy } \\
(\mathrm{MeV})\end{array}$ & $\begin{array}{c}\text { Activity } \\
\text { (Photons/sec) }\end{array}$ & \begin{tabular}{|c|} 
Fluence \\
Rate \\
$\mathrm{MeV} / \mathrm{cm}^{2} / \mathrm{sec}$ \\
No Buildup \\
\end{tabular} & \begin{tabular}{|c|} 
Fluence Rate \\
$\mathrm{MeV} / \mathrm{cm}^{2} / \mathrm{sec}$ \\
With \\
Buildup \\
\end{tabular} & $\begin{array}{c}\text { Exposure } \\
\text { Rate } \\
\text { mR/hr } \\
\text { No Buildup }\end{array}$ & $\begin{array}{c}\text { Exposure } \\
\text { Rate } \\
\text { mR/hr } \\
\text { With Buildup }\end{array}$ \\
\hline 0.6938 & $6.035 \mathrm{e}+06$ & $7.328 \mathrm{e}+01$ & $8.923 \mathrm{e}+01$ & $1.415 \mathrm{e}-01$ & $1.723 \mathrm{e}-01$ \\
\hline 1.1732 & $3.700 \mathrm{e}+10$ & $8.064 \mathrm{e}+05$ & $9.325 \mathrm{e}+05$ & $1.441 \mathrm{e}+03$ & $1.666 \mathrm{e}+03$ \\
\hline 1.3325 & $3.700 \mathrm{e}+10$ & $9.280 \mathrm{e}+05$ & $1.061 \mathrm{e}+06$ & $1.610 \mathrm{e}+03$ & $1.841 \mathrm{e}+03$ \\
\hline Totals & $7.401 e+10$ & $1.734 \mathrm{e}+06$ & $1.994 e+06$ & $3.051 e+03$ & $3.508 e+03$ \\
\hline \multicolumn{6}{|c|}{ Results - Dose Point \# 3 - $(31.51251,60.96,0) \mathrm{cm}$} \\
\hline $\begin{array}{l}\text { Energy } \\
(\mathrm{MeV})\end{array}$ & $\begin{array}{c}\text { Activity } \\
\text { (Photons/sec) }\end{array}$ & \begin{tabular}{|c|} 
Fluence \\
Rate \\
$\mathrm{MeV} / \mathrm{cm}^{2} / \mathbf{s e c}$ \\
No Buildup
\end{tabular} & \begin{tabular}{|c|} 
Fluence Rate \\
$\mathrm{MeV} / \mathrm{cm}^{2} / \mathrm{sec}$ \\
With \\
Buildup
\end{tabular} & $\begin{array}{c}\text { Exposure } \\
\text { Rate } \\
\text { mR/hr } \\
\text { No Buildup }\end{array}$ & $\begin{array}{c}\text { Exposure } \\
\text { Rate } \\
\text { mR/hr } \\
\text { With Buildup }\end{array}$ \\
\hline 0.6938 & $6.035 \mathrm{e}+06$ & $1.379 \mathrm{e}+02$ & $1.692 \mathrm{e}+02$ & $2.662 \mathrm{e}-01$ & $3.267 \mathrm{e}-01$ \\
\hline 1.1732 & $3.700 \mathrm{e}+10$ & $1.522 \mathrm{e}+06$ & $1.776 \mathrm{e}+06$ & $2.719 \mathrm{e}+03$ & $3.174 \mathrm{e}+03$ \\
\hline 1.3325 & $3.700 \mathrm{e}+10$ & $1.752 \mathrm{e}+06$ & $2.023 \mathrm{e}+06$ & $3.040 \mathrm{e}+03$ & $3.509 \mathrm{e}+03$ \\
\hline
\end{tabular}




\begin{tabular}{|c|c|c|c|c|c|}
\hline Totals & $7.401 e+10$ & $3.274 \mathrm{e}+06$ & $3.799 \mathrm{e}+06$ & $5.759 e+03$ & $6.684 e+03$ \\
\hline \multicolumn{6}{|c|}{ Results - Dose Point \# 4 - $(31.51251,99.21875,0) \mathrm{cm}$} \\
\hline $\begin{array}{c}\text { Energy } \\
(\mathrm{MeV})\end{array}$ & $\begin{array}{c}\text { Activity } \\
\text { (Photons/sec) }\end{array}$ & \begin{tabular}{|c|} 
Fluence \\
Rate \\
MeV/cm²/sec \\
No Buildup
\end{tabular} & \begin{tabular}{|c|} 
Fluence Rate \\
$\mathrm{MeV} / \mathrm{cm}^{2} / \mathrm{sec}$ \\
With \\
Buildup \\
\end{tabular} & $\begin{array}{c}\text { Exposure } \\
\text { Rate } \\
\text { mR/hr } \\
\text { No Buildup }\end{array}$ & $\begin{array}{c}\text { Exposure } \\
\text { Rate } \\
\text { mR/hr } \\
\text { With Buildup }\end{array}$ \\
\hline 0.6938 & $6.035 \mathrm{e}+06$ & $3.910 \mathrm{e}+01$ & $5.276 \mathrm{e}+01$ & $7.549 \mathrm{e}-02$ & $1.019 \mathrm{e}-01$ \\
\hline 1.1732 & $3.700 \mathrm{e}+10$ & $4.449 \mathrm{e}+05$ & $5.593 \mathrm{e}+05$ & $7.951 \mathrm{e}+02$ & $9.995 \mathrm{e}+02$ \\
\hline 1.3325 & $3.700 \mathrm{e}+10$ & $5.160 \mathrm{e}+05$ & $6.385 \mathrm{e}+05$ & $8.952 \mathrm{e}+02$ & $1.108 \mathrm{e}+03$ \\
\hline Totals & $7.401 e+10$ & $9.609 e+05$ & $1.198 \mathrm{e}+06$ & $1.690 \mathrm{e}+03$ & $2.107 \mathrm{e}+03$ \\
\hline \multicolumn{6}{|c|}{ Results - Dose Point \# 5 - $(31.51251,137.4775,0) \mathrm{cm}$} \\
\hline $\begin{array}{c}\text { Energy } \\
(\mathrm{MeV})\end{array}$ & $\begin{array}{c}\text { Activity } \\
\text { (Photons/sec) }\end{array}$ & \begin{tabular}{|c|} 
Fluence \\
Rate \\
$\mathrm{MeV} / \mathrm{cm}^{2} / \mathrm{sec}$ \\
No Buildup
\end{tabular} & \begin{tabular}{|c|} 
Fluence Rate \\
$\mathrm{MeV} / \mathrm{cm}^{2} / \mathrm{sec}$ \\
With \\
Buildup \\
\end{tabular} & $\begin{array}{c}\text { Exposure } \\
\text { Rate } \\
\text { mR/hr } \\
\text { No Buildup }\end{array}$ & $\begin{array}{c}\text { Exposure } \\
\text { Rate } \\
\text { mR/hr } \\
\text { With Buildup }\end{array}$ \\
\hline 0.6938 & $6.035 \mathrm{e}+06$ & $1.380 \mathrm{e}+01$ & $2.054 \mathrm{e}+01$ & $2.665 \mathrm{e}-02$ & $3.965 \mathrm{e}-02$ \\
\hline 1.1732 & $3.700 \mathrm{e}+10$ & $1.624 \mathrm{e}+05$ & $2.202 \mathrm{e}+05$ & $2.903 \mathrm{e}+02$ & $3.936 \mathrm{e}+02$ \\
\hline 1.3325 & $3.700 \mathrm{e}+10$ & $1.898 \mathrm{e}+05$ & $2.521 \mathrm{e}+05$ & $3.293 \mathrm{e}+02$ & $4.373 \mathrm{e}+02$ \\
\hline Totals & $7.401 e+10$ & $3.523 \mathrm{e}+05$ & $4.723 e+05$ & $6.196 e+02$ & $8.309 \mathrm{e}+02$ \\
\hline
\end{tabular}


8.5 APPENDIX E - UNDERWATER ON CONTACT MICROSHIELD MODEL

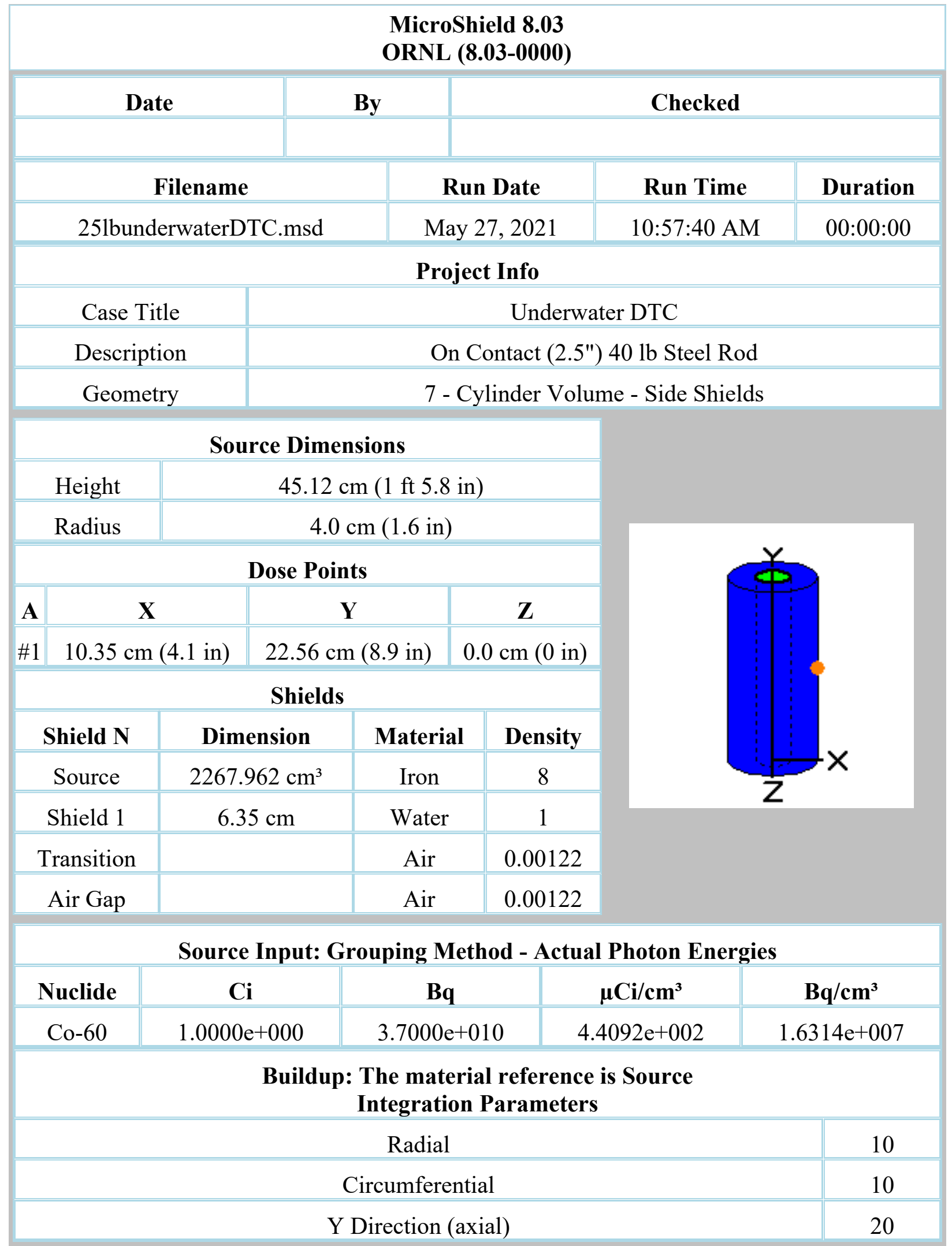




\begin{tabular}{|c|c|c|c|c|c|}
\hline \multicolumn{6}{|c|}{ Results } \\
\hline $\begin{array}{l}\text { Energy } \\
(\mathrm{MeV})\end{array}$ & $\begin{array}{c}\text { Activity } \\
\text { (Photons/sec) }\end{array}$ & \begin{tabular}{|c|} 
Fluence \\
Rate \\
$\mathrm{MeV} / \mathrm{cm}^{2} / \mathrm{sec}$ \\
No Buildup \\
\end{tabular} & $\begin{array}{l}\text { Fluence Rate } \\
\text { MeV/cm } / \mathrm{cm}^{2} / \mathrm{sec} \\
\text { With } \\
\text { Buildup }\end{array}$ & $\begin{array}{c}\text { Exposure } \\
\text { Rate } \\
\text { mR/hr } \\
\text { No Buildup }\end{array}$ & $\begin{array}{c}\text { Exposure } \\
\text { Rate } \\
\text { mR/hr } \\
\text { With Buildup }\end{array}$ \\
\hline 0.6938 & $6.035 \mathrm{e}+06$ & $1.793 \mathrm{e}+02$ & $4.753 \mathrm{e}+02$ & $3.463 \mathrm{e}-01$ & $9.177 \mathrm{e}-01$ \\
\hline 1.1732 & $3.700 \mathrm{e}+10$ & $2.730 \mathrm{e}+06$ & $6.061 \mathrm{e}+06$ & $4.879 \mathrm{e}+03$ & $1.083 \mathrm{e}+04$ \\
\hline 1.3325 & $3.700 \mathrm{e}+10$ & $3.389 \mathrm{e}+06$ & $7.195 \mathrm{e}+06$ & $5.880 \mathrm{e}+03$ & $1.248 \mathrm{e}+04$ \\
\hline Totals & $7.401 \mathrm{e}+10$ & $6.119 e+06$ & $1.326 e+07$ & $1.076 \mathrm{e}+04$ & $2.331 \mathrm{e}+04$ \\
\hline
\end{tabular}

